\title{
Insight into the role of microRNAs in brain tumors (Review)
}

\author{
ALESSIA CATANIA $^{1}$, FRANCESCA MAIRA ${ }^{1}$, EVANGELIA SKARMOUTSOU ${ }^{1}$, FABIO D'AMICO ${ }^{1}$, \\ ROGER ABOUNADER $^{2}$ and MARIA CLORINDA MAZZARINO ${ }^{1}$ \\ ${ }^{1}$ Department of Bio-medical Sciences, University of Catania, Catania, Italy; ${ }^{2}$ Department of Microbiology, \\ University of Virginia, Charlottesville, VA 22908, USA
}

Received July 30, 2011; Accepted September 26, 2011

DOI: 10.3892/ijo.2011.1305

\begin{abstract}
MicroRNAs (MiRNAs) are small non-coding RNAs able to regulate gene expression at a posttranscriptional level. Recent evidence indicates that they play a crucial role in the initiation and progression of human cancers. In this review we briefly describe microRNA biogenesis and function, giving a more detailed account of the current state of knowledge concerning the role of microRNAs in brain tumors and stem-like tumor cells. MicroRNAs control brain tumor development by regulating multiple biological characteristics such as proliferation, invasion, differentiation and angiogenesis. Research in this field is rapidly spreading and encourages potential applications of microRNAs as diagnostic and prognostic tools, in addition to therapeutic targets and tools, to grant clinical benefits to patients suffering of brain tumors.
\end{abstract}

\section{Contents}

1. Introduction

2. MicroRNAs and cancer

3. MicroRNAs in gliomas and glioblastoma

4. MiRNAome profiling analysis

5. Mir-21

6. Mir-221/222

7. Mir-34a

8. Mir-128

9. Mir-451

10. Mir-7

11. Mir- 181

12. Mir-124/137

13. Mir- 125

14. Mir-326

15. Mir-26a

Correspondence to: Dr Alessia Catania, Department of Bio-medical Sciences, University of Catania, Via Androne 83, I-95124 Catania, Italy

E-mail: alessiacatania@hotmail.it

Key words: microRNAs, glioma, tumor stem cells, medulloblastoma, pituitary tumors
16. Mir-10b

17. Mir-15b

18. Mir-146b

19. Mir-296

20. Mir-29

21. MiR-17-92 cluster

22. Let-7

23. MicroRNAs and tumor stem cells

24. MicroRNAs in medulloblastoma

25. MicroRNAs in pituitary tumors

26. Conclusion and future perspectives

\section{Introduction}

MicroRNAs are small non-coding RNAs of about 22 nucleotides which regulate gene expression in a sequence-dependent and mainly posttranscriptional manner, as they are able to bind to complementary regions in the 3'-untranslated region (UTR) of target genes, leading to transcript silencing (1), either by destabilization and degradation of the target mRNA $(2,3)$, or by repression of translation (4). However, it has recently been discovered that they can also stimulate translation or regulate transcription through binding to gene promoters $(5,6)$. MiRNAs are transcribed as longer pri-miRNAs ( $\sim 60-110 \mathrm{nt})$ by polymerase II or III and their maturation occurs through a series of nuclear and cytoplasmic cleavages. The first nuclear cleavage is mediated by an RNase III endonuclease called Drosha to form approximately 70 nucleotide-long intermediate molecule (premiRNA). Precursor miRNAs are transported to the cytoplasm by exportin-5 (7) where they are cleaved by the RNase III Dicer (acting in concert with a dsRNA binding protein, TRBP) into small miRNA duplexes, composed of the mature miRNA and its complementary strand $(8,9)$. When the miRNA complementary strand is degraded, the mature miRNA can be incorporated into the RISC complex (RNAinduced silencing complex) via association with an Argonaute family protein, Ago2 (10), finally leading to posttranscriptional silencing of the target gene(s) (Fig. 1).

More than 900 annotated miR sequences in human genome are available in the latest update of miRBase (April 2010, http:// www.mirbase.org/) and they are thought to regulate more than one third of human genes (11). Each miRNA can target 200 transcripts directly or indirectly, whereas more than one miRNA can converge on a single protein-coding gene target 
(7). Nevertheless, in a recent in-depth analysis of human 3'-UTR sequences, even $>60 \%$ of human protein-coding genes resulted being under selective pressure to maintain pairing to miRNAs (12). Available from: http://www.targetscan.org. (latest update April 2009, release 5.1).

MiRNAs are expressed in a tissue-specific manner, but their biological functions are not completely understood. It is already widely accepted that miRNAs are involved in the regulation of multiple cellular processes, such as neuronal development, cellular differentiation, apoptosis, proliferation, and their expression is deregulated in many human cancers contributing to cancer initiation and progression $(13,14)$.

\section{MicroRNAs and cancer}

The first connection between B-cell chronic lymphocytic leukemia (CLL) and microRNA-15 and -16 was established by Calin $e t a l$ in 2002 (15). Following this discovery, a large wealth of data have been generated to better understand how microRNAs function in neoplastic cells. Nevertheless aberrant miRNAs expression patterns have been demonstrated in essentially every kind of cancer studied due to mutations, polymorphism, chromosomal or epigenetic changes and defects (above all changes in genomic DNA methylation pattern) in microRNA biogenesis machinery (16). Approximately half of the microRNAs discovered to date are located near fragile sites, in loci associated with loss of heterozygosity, in loci associated with DNA amplification, and in common breakpoints (17).

These data suggest that miRNAs are implicated in tumorigenesis, both as oncogenes or tumor suppressor genes. As they are down- or up-regulated in tumors, microRNAs may affect the expression of genes that are involved in cell cycle, regulation of cell proliferation, apoptosis, angiogenesis, immune response, tumor invasion and metastasis, and genomic instability of cancer cells (18).

In light of this association, the recent high-throughput analyses and microarray technologies have reported altered miRNA expression in all tumors investigated to date. It has led to the definition of the so-called miRNAome, the global expression pattern of microRNAs in each tumor. Besides the identification of miRNAs differentially expressed between normal and tumor samples, microarray analysis could identify miRNA expression signatures associated with well-defined clinicopathologic features (such as diagnosis, progression and metastatic phenotype) and disease outcome and prognosis $(14,19,20)$.

\section{MicroRNAs in gliomas and glioblastoma}

Malignant gliomas that arise from brain glial cells are the most common primary brain tumors comprising $>50 \%$ upon the whole (21). According to the Central Brain Tumor Registry of the United States (CBTRUS) 2007-2008 report, 16.5 new cases per 100,000 persons/year are diagnosed in the US, meaning there are more than 50,000 new diagnosis of glioma every year (22). Gliomas include a wide range of malignancies classified from slow growing to highly aggressive tumors. World Health Organization (WHO) classifies gliomas by grades on the basis of their histological features: grade I (pilocytic astrocytoma), grade II (diffuse astrocytoma), grade III (anaplastic astrocytoma), and grade IV (glioblastoma multiforme, GBM) (23).
While grade I have a good clinical outcome, grades II and III contain a gradually increasing amount of anaplastic cells and mitotic activity with an inconstant potential to progress to higher grades and to be lethal. Glioblastoma multiforme (GBM) is the most malignant and deadliest glioma, with a life expectancy of average 14 months after diagnosis, despite aggressive surgery, radiation, and chemotherapies. Primary glioblastomas arise de novo with no prior clinical disease, while a shorter rate of glioblastomas, called 'secondary', develop from a lower grade glioma $(24,25)$. The presence of areas of vascular proliferation and necrosis is the typical histological feature of GBM, that explains their high proliferative activity and their resistance to radiation and chemotherapy (26).

Recent discoveries in neuro-oncology have extended our knowledge on gliomas genetics and molecular pathogenesis, and they are likely to help the development of future therapeutic intervention.

\section{MiRNAome profiling analysis}

Profiling techniques to identify global expression patterns of microRNAs in brain tumors have been widely used to uncover aberrantly expressed microRNAs in tumor genomes (Table I). The first studies used microarray technologies and Northern blotting on tumor tissue samples $(27,28)$.

Besides, dysregulated miRNA population can be characterized by using high sensitive and specific TaqMan-based RT-PCR approaches following the retention and purification of RNA in the size range of 10-200 bases (29). Microarray chips offer the advantage of covering a wide range of microRNAs, even though a higher amount of RNA is required and probes specificity is overall lower if compared to PCR. MiRNAome can also be analyzed from formalin-fixed and paraffin-embedded tissue as demonstrated by a miRNA profiling that used an RNA primed, array-based, Klenow enzyme (RAKE) microarray platform, a technique analogous to standard oligonucleotide arrays (30).

One of the first microarray studies examined global expression of 245 miRNAs in glioblastoma tissue and cell lines versus normal brain tissue: most notably a strong upregulation of miR-221 in glioblastoma was found while miR-128, miR-181a, miR-181b, and miR-181c were downregulated (28). Chan et al, detected the expression patterns of 180 miRNAs in high grade gliomas, highlighting for the first time the upregulation of mir21 and confirming these results by Northern blot analysis (27).

RT-PCR studies to assess 192 microRNAs expression in highgrade astrocytomas showed a downregulation of microRNA-124 and microRNA-137 in anaplastic astrocytoma and glioblastoma multiforme compared to normal brain and, consistent with previous observations, an upregulation of mir-21 (29). A recent work by Liu et al evaluated genome-wide mRNA expression levels by microarray analysis and a miRNA profiling by RTPCR on 12 brain tumor samples. They detected a set of highly correlated miRNAs-mRNAs and then validated the putative pairs by over-expressing or suppressing the implicated miRNA and measuring the presumable targeted mRNA levels. MiR-181c was found to be positively related to the expression of PCAF, which in turn leads to upregulation of the tumor suppressor $\mathrm{p} 53$, thus explaining the anti-proliferative potential of this microRNA (31). 
MicroRNAs could also be used as promising biomarkers for brain tumors. In an extensive microarray profiling carried on a set of 252 tumor samples including 15 brain primary tumor samples, 187 non-brain primary tumors, and 50 brain metastases from various tissue origins, Nass et al showed that miR-92b and miR-9/9*, previously found to be overexpressed in brain stem cells and during neuronal development $(32,33)$, are significantly overexpressed in primary brain tumors samples, but not in metastatic brain tumor samples. The results were further validated by qRT-PCR. These observations suggest that combined determination of miR-92b and miR-9/9* levels could represent a valid biomarker to identify primary brain tumors and discriminate them from brain metastasis with very high accuracy and further support the hypothesis of a strong connection between stemness and tumorigenesis (34).

The most recent genome wide microRNA profiling in glioblastomas and anaplastic astrocytomas was performed by Rao et al in 2010, who identified a set of 84 miRNAs differentially expressed in malignant astrocytoma in comparison with normal brain. Additionally, they identified miRNA signatures that can differentiate secondary glioblastoma and primary glioblastoma from anaplastic astrocytoma (23 miRNAs differentially regulated with an accuracy of 94.8\%), secondary glioblastoma from primary glioblastoma ( $7 \mathrm{miRNAs}$ differentially regulated), and progressive astrocytoma from de novo glioblastoma (21 miRNAs differentially regulated), which are likely to lead to a rapid and accurate molecular diagnostic test in the future. Furthermore, they detected and later confirmed by RT-PCR, the grade specificity of 9 miRNAs in malignant astrocytomas. Anti-miR mediated downregulation of miR-21 and miR-23a and exogenous overexpression of mir-218 and mir-219 by transfection in glioma cells, resulted in significant reduction in their ability to form colonies in soft agar, confirming their role in astrocyte transformation and tumor growth (35).

\section{Mir-21}

Mir-21 is one of the most overexpressed miRNAs in human tumors and plays a key role in many cancers such as pancreatic cancer, colorectal cancer, liver cancer, breast cancer and glioblastomas (36). Interestingly, in a mouse model of breast adenocarcinoma, mir-21 knockdown leads to inhibition of tumor cell growth and is associated with downregulation of Bcl-2 expression, an antiapoptotic regulatory factor (37).

Microarray profiling studies, further validated by Northern blotting qRT-PCR and real-time PCR analysis, showed that microRNA-21 is strongly elevated in glioma and glioblastoma tumor samples and glioma cell lines when compared to nonneoplastic control samples, and upregulation is particularly prominent in grade IV astrocytomas $(27,28,38-40)$. In a group of four patients with primary WHO grade II gliomas that spontaneously progressed to WHO grade IV secondary glioblastomas, mir-21 levels gradually increased, suggesting that mir-21 could have a role in glioma progression (41). Zhi et al assessed levels of 200 miRNAs from 124 astrocytoma samples and 60 normal adjacent tissue samples via qRT-PCR. Mir-21 was shown to be upregulated during astrocytic tumorigenesis and located within a chromosome region of frequent genomic alterations. High expression of miR-21 was significantly associated with poor patient survival, suggesting that, in combination with other aberrant expressed microRNAs (low expression of miR-181b or miR-106a), miRNA-21 profiling has potential application as novel diagnostic and prognostic indicator that may contribute to improve the selection of patients for adjuvant therapy and to predict the post-surgical outcome (39).

Furthermore, suppression of mir-21 in glioblastoma cells with locked-nucleic acid (LNA) or 20-O-methyl-oligoribonucleotides antisense oligonucleotides, decreased the metabolic activity of cell culture and cell number, and was associated with a marked increase in apoptosis and caspase activation (27). MiR-21 knockdown by LNA oligonucleotides also leads to a considerable reduction of glioma volumes in mouse xenografts (42). Mir-21 antiapoptotic activity has been further demonstrated in a great number of studies: mir-21 downregulation in glioma cell lines by antisense oligonucleotides inhibited proliferation and cell invasion and induced apoptosis through the activation of caspase-3 and -9 , which in turn, may be related to a mir-21-dependent modulation of multiple potential target genes, such as TIMP3 $(43,44)$.

From an in silico constructed study of miR-21 predicted targets and further pathway analysis of computer generated lists of the identified target genes, emerged that mir-21 targets multiple components of the $\mathrm{p} 53$, transforming growth factor- $\beta$ (TGF- $\beta$ ) and mitochondrial apoptosis pathways, that contribute to its tumor promoting and antiapoptotic activity. The phenotypic effects observed upon downregulation of miR-21 in glioblastoma cells, reflect the repression of these pathways and result in significant increase in apoptotic cells, reduced growth and cell cycle arrest at G0-G1 (45). Further bioinformatics analysis evidenced that multiple genes involved in apoptosis pathways (such as PDCD4, MTAP, and SOX5), carry putative miR-21 binding sites. PDCD4 mRNA is a direct functional target of miR-21 and its expression inversely correlates with mir-21 in a number of glioblastoma cell lines (T98G, A172, U87, and U251). Consistent with these observations, downregulation of mir-21 restored protein level of PDCD4 while, ectopic overexpression of mir-21, inhibits PDCD4-dependent apoptosis (46). Mir-21 controls tumor invasiveness and microvascular proliferation by regulating the expression of two of the major inhibitors of matrix metalloproteinases (MMPs): RECK, a membrane-anchored regulator, and TIMP3, the ECM-bound protease regulator. Mir-21 knockdown decreases RECK and TIMP3 protein levels and MMPs activity both in vivo and in vitro leading to a reduction of glioma cell motility and invasion. Consistent with these findings RECK and TIMP3 levels drop, whereas miR-21 expression increases during glioma progression to higher grades (40). Although PTEN tumor suppressor gene has been validated as a miR-21 target by computational analysis $(47,48)$, down-regulation of mir-21 by specific antisense oligonucleotide leads to an inhibition of tumor growth in glioblastoma cell lines and xenograft tumors independently of PTEN mutational status. This is particularly interesting as up to $80 \%$ of GBMs have a PTEN deficiency, and the prognosis of GBM can be predicted based on the levels of expression of PTEN (49,50). MiRNA expression profile scanning data after inhibition of miR-21, strongly indicated that BID, FAS, PRS6, and SOCS4 tumor suppressor genes were upregulated and evidenced a suppression of EGFR, activated Akt, cyclin D, and Bcl-2. This study highlighted that miR-21 targets multiple, (and possibly yet unknown), pathways responsible of inhibition of glioma growth in absence of PTEN (51). 
Table I. Biological effects of microRNA in gliomas and glioma stem cells (GSCs) and medulloblastoma.

\begin{tabular}{|c|c|c|c|c|}
\hline MicroRNA & Expression level & Putative target genes & Biological/clinical effects & Refs. \\
\hline \multicolumn{5}{|l|}{$\begin{array}{l}\text { Gliomas and glioma } \\
\text { stem cells (GSCs) }\end{array}$} \\
\hline Mir-21 & Up-regulated & $\begin{array}{l}\text { PDCD4, RECK, } \\
\text { TIMP3, PTEN, } \\
\text { LRRFIP1 }\end{array}$ & $\begin{array}{l}\text { Promotion of growth, } \\
\text { proliferation, invasion and cell } \\
\text { cycle progression, apoptosis } \\
\text { inhibition. Putative diagnostic } \\
\text { and prognostic marker. } \\
\text { Reduction of sensitivity } \\
\text { against cytotoxic therapy. }\end{array}$ & $\begin{array}{l}(27,28,38-40,42, \\
44-48,51-53,57)\end{array}$ \\
\hline Mir 221/222 & Up-regulated & $\begin{array}{l}\text { p57, p27, PUMA, } \\
\text { members of Akt } \\
\text { pathway }\end{array}$ & $\begin{array}{l}\text { Promotion of growth, } \\
\text { proliferation, cell cycle } \\
\text { progression and invasion, } \\
\text { inhibition of apoptosis. }\end{array}$ & $(28,61-66)$ \\
\hline Mir-34a & Downregulated & $\begin{array}{l}\text { c-Met, Notch-1/ } \\
\text { Notch-2, SIRT1 } \\
\text { (silent information } \\
\text { regulator 1) }\end{array}$ & $\begin{array}{l}\text { Inhibition of growth, } \\
\text { proliferation, cell cycle } \\
\text { progression, cell survival and } \\
\text { invasion. Induction of } \\
\text { differentiation. }\end{array}$ & $(67-69,73,75)$ \\
\hline Mir-128 & Downregulated & $\begin{array}{l}\text { Bmi-1, E2F3a, ARP5 } \\
\text { (angiopoietin-related } \\
\text { protein 5) }\end{array}$ & $\begin{array}{l}\text { Inhibition of glioma } \\
\text { proliferation and growth, } \\
\text { promotion of differentiated } \\
\text { phenotype. }\end{array}$ & $(80)$ \\
\hline Mir-451 & Contrasting results & $\begin{array}{l}\text { Members of PI3K/ } \\
\text { AKT pathway, CAB39 }\end{array}$ & $\begin{array}{l}\text { Controversial effects. Role in } \\
\text { GSCs proliferation. }\end{array}$ & $(80,87-89,91,92)$ \\
\hline Mir-7 & Downregulated & $\begin{array}{l}\text { EGFR, IRS-1, IRS-2, } \\
\text { Raf1 }\end{array}$ & $\begin{array}{l}\text { Inhibition of viability and } \\
\text { invasiveness, induction of cell } \\
\text { cycle arrest and apoptosis. }\end{array}$ & $(94-96)$ \\
\hline Mir-181a & Downregulated & Not applicable & $\begin{array}{l}\text { Inhibition of cell growth and } \\
\text { invasion, apoptosis induction. }\end{array}$ & $(28,38,100)$ \\
\hline Mir-181b & Downregulated & Not applicable & $\begin{array}{l}\text { Inhibition of cell growth and } \\
\text { invasion, apoptosis induction. } \\
\text { Putative diagnostic and } \\
\text { prognostic marker. }\end{array}$ & $(28,38,39,100)$ \\
\hline Mir-124; Mir-137 & Downregulated & CDK6 & $\begin{array}{l}\text { Promotion of differentiation } \\
\text { and cell cycle arrest. }\end{array}$ & $(27-29)$ \\
\hline Mir-125a & Downregulated & Podoplanin (PDPN) & Inhibition of glioma invasion & $(110)$ \\
\hline Mir-125b & & $\mathrm{p} 53, \mathrm{Bmf}$ & $\begin{array}{l}\text { Suppression of } \mathrm{p} 53 \text {-mediated } \\
\text { apoptosis, induction of } \\
\text { differentiation. }\end{array}$ & $(107,108,157)$ \\
\hline Mir-326 & Downregulated & $\begin{array}{l}\text { PKM2, members of } \\
\text { Notch-1 pathway }\end{array}$ & $\begin{array}{l}\text { Inhibition of proliferation, } \\
\text { viability and invasiveness, } \\
\text { induction of apoptosis. }\end{array}$ & $(158)$ \\
\hline Mir-26a & Up-regulated & $\begin{array}{l}\text { PTEN, RB1, } \\
\text { MAP3K2/MEKK2 }\end{array}$ & $\begin{array}{l}\text { Promotion of tumor growth } \\
\text { and inhibition of apoptosis. }\end{array}$ & $(87,112)$ \\
\hline Mir-10b & Up-regulated & $\begin{array}{l}\text { Homeobox D10 } \\
\text { (HOXD10) }\end{array}$ & $\begin{array}{l}\text { Positive correlation with tumor } \\
\text { grade and multifocal lesions, } \\
\text { involvement in regulation of } \\
\text { invasion and migration. }\end{array}$ & $(114)$ \\
\hline
\end{tabular}


Table I. Continued.

\begin{tabular}{|c|c|c|c|c|}
\hline MicroRNA & Expression level & Putative target genes & Biological/clinical effects & Refs. \\
\hline Mir-15b & Up-regulated & CCNE1 (cyclin E1) & $\begin{array}{l}\text { Inhibition of cell cycle } \\
\text { progression. }\end{array}$ & $(115)$ \\
\hline Mir-146b & Downregulated & $\begin{array}{l}\text { MMP16 } \\
\text { (metalloproteinase 16) }\end{array}$ & $\begin{array}{l}\text { Inhibition of glioma metastatic } \\
\text { phenotype (migration and } \\
\text { invasion). }\end{array}$ & $(116)$ \\
\hline Mir-296 & & $\begin{array}{l}\text { HGS (hepatocyte } \\
\text { growth factor-regulated } \\
\text { tyrosine kinase substrate) }\end{array}$ & $\begin{array}{l}\text { Promotion of cancer } \\
\text { angiogenesis by increasing } \\
\text { response to VEGF (vascular } \\
\text { endothelial growth factor). }\end{array}$ & $(117)$ \\
\hline Mir-29 & Downregulated & $\begin{array}{l}\text { Podoplanin (PDPN), } \\
\text { B7-H3 }\end{array}$ & $\begin{array}{l}\text { Inhibition of glioma invasion } \\
\text { and proliferation, induction of } \\
\text { apoptosis, reduction of glioma } \\
\text { immune escape. }\end{array}$ & $(110)$ \\
\hline Mir-17-92 cluster & Up-regulated & $\begin{array}{l}\text { CDKN1, E2F1, } \\
\text { PTEN, CTGF }\end{array}$ & $\begin{array}{l}\text { Control of glioma } \\
\text { differentiation, viability and } \\
\text { proliferation. }\end{array}$ & $(121)$ \\
\hline Let-7 & & RAS family & $\begin{array}{l}\text { Impairment of glioma growth } \\
\text { and migration. }\end{array}$ & $(131)$ \\
\hline \multicolumn{5}{|l|}{ Medulloblastomas } \\
\hline Mir-125a & Downregulated & $\mathrm{t}-\mathrm{TrkC}$ & $\begin{array}{l}\text { Promotion of apoptosis and } \\
\text { impairing of anchorage- } \\
\text { independent growth. }\end{array}$ & $(165)$ \\
\hline Mir-9 & Downregulated & $\begin{array}{l}\text { REST/NRSF, } \\
\text { t-TrkC }\end{array}$ & $\begin{array}{l}\text { Promotion of apoptosis and } \\
\text { impairing of anchorage- } \\
\text { independent growth. }\end{array}$ & $(165,169)$ \\
\hline Mir-124 & Downregulated & $\begin{array}{l}\text { CDK6, REST/NRSF, } \\
\text { SLC16A1 }\end{array}$ & Inhibition of cell growth. & $(168-170,176)$ \\
\hline Mir-17 & Up-regulated & TOPORS, BAMBI & Putative oncogene & $(177)$ \\
\hline Mir-106b & Up-regulated & & Putative oncogene & $(177)$ \\
\hline Mir-100 & Up-regulated & BTG2 & Putative oncogene & $(177)$ \\
\hline Mir-218 & Downregulated & EGFR, CTNND2 & Putative tumor suppressor & $(177)$ \\
\hline $\begin{array}{l}\text { MiR-125b, MiR-326, } \\
\text { MiR-324-5p }\end{array}$ & Downregulated & Smo and Gli1 & $\begin{array}{l}\text { Inhibition of downstream } \\
\text { components of SHH signalling. }\end{array}$ & $(180)$ \\
\hline MiR-17-92 cluster & Up-regulated & Not determined & $\begin{array}{l}\text { Promotion of cell growth in } \\
\text { cooperation with SHH pathway. }\end{array}$ & $(182,183)$ \\
\hline Mir-199-5p & $\begin{array}{l}\text { Downregulated } \\
\text { (especially in } \\
\text { metastatic tumors) }\end{array}$ & HES1 & $\begin{array}{l}\text { Reduction of tumor growth } \\
\text { and proliferation, promotion } \\
\text { of differentiation. }\end{array}$ & $(188)$ \\
\hline MiR-128a & Downregulated & Bmi-1 & $\begin{array}{l}\text { Inhibition of tumor growth and } \\
\text { proliferation, induction of } \\
\text { premature senescence. }\end{array}$ & $(190)$ \\
\hline MiR-34a & & c-Met & $\begin{array}{l}\text { Inhibition of proliferation, cell cycle } \\
\text { progression, invasion and survival. }\end{array}$ & (68) \\
\hline
\end{tabular}

Further findings strengthened the hypothesis that miR-21 represents a promising target to improve the efficacy of chemo- therapy. In a recent study mir-21 was shown to play a key role in promoting human glioblastoma cells U87MG resistance against 


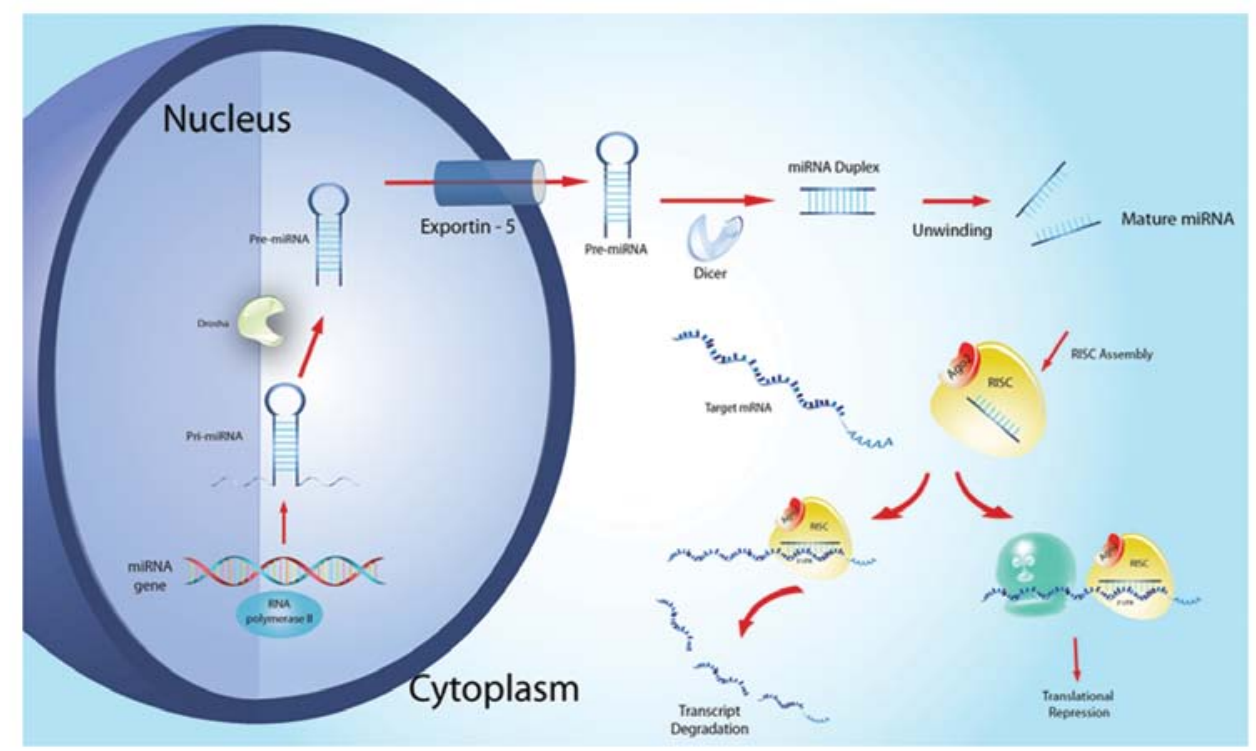

Figure 1. MicroRNA biogenesis. MicroRNAs are transcribed by RNA polymerase II to produce pri-miRNAs. Pri-miRNAs are cleaved by the endoribonuclease Drosha to form a hairpin loop structure precursor (pre-miRNA). Pre-miRNAs are then exported out of the nucleus to the cytoplasm by the protein exportin 5 and they further undergo maturation through another catalytic step mediated by Dicer to form miRNA duplexes. When the complementary strand is degraded the mature miRNA is incorporated into the RISC complex via association with Ago2 protein. Recognition of target mRNA is directed by sequence complementarity and leads to posttranscriptional silencing by inducing mRNA degradation and/or inhibiting the translation of the mRNA.

the antitumoral agent temozolomide (TMZ). Indeed, ectopic overexpression of mir-21 significantly reduced TMZ-induced apoptosis in this cell line through a suppression of $\mathrm{Bax} / \mathrm{Bcl}-2$ ratio and caspase- 3 activity. These results confirm the hypothesis that mir-21 overexpression during glioma progression could be responsible of clinical resistance to chemotherapy with the promising alkylating agent TMZ (52). Li et al in 2009, demonstrated that mir-21 is also involved in glioblastoma cell chemoresistance to the chemotherapeutic agent VM-26, as shown by the observation that miR-21 knockdown sensitized GBM cells to VM-26. This is likely to happen because mir-21 regulates and inhibit LRRFIP1 gene expression by direct interaction (53). This gene encodes a protein, also known as the TRAF-interacting protein (TRIP), that inhibits $\mathrm{NF}-\mathrm{kB}$ signaling, a pathway that is known to be responsible for protection against apoptosis (54) and tumor chemoresistance $(55,56)$. Additionally, suppression of microRNA-21 expression in glioblastoma cell lines enhances sensitivity of cancer cells to antineoplastic cytotoxic therapy with neural precursor cells (NPC) expressing a secretable variant of the cytotoxic agent tumor necrosis factor related apoptosis inducing ligand (S-TRAIL). The synergistic effect was observed both in vitro, through an increased caspase associated cytotoxic death, and in vivo, where miR-21 knockdown and NPC-mediated S-TRAIL reduce cancer growth in tumor xenografts (42). A recent study that evaluated the potential role of mir-21 as a therapeutic tool to enhance the cytotoxic effect of standard chemotherapy showed that co-delivery of miR-21 and 5-fluorouracil (5-FU) by using a poly(amidoamine) (PAMAM) dendrimer as a carrier, significantly improved the cytotoxicity of the antitumor agent leading to an higher apoptosis rate and a reduction of the migration ability of tumor cells (57). Finally, downregulation of miR-21, contributes to the antitumor effects of IFN- $\beta$ on glioma cell and intracranial tumor xenografts and the activation of the transcription factor STAT3 may have a key role in the IFN- $\beta$ mediated suppression of mir-21 (58).
These preliminary findings suggest that overexpressed miR-21 may function as a micro-oncogene in glioblastomas by blocking expression of key apoptosis-enabling genes. Therefore, modulation of mir-21 expression could provide a novel therapeutic approach to glioma targeted therapy, as it represents a regulator of a wide range of pathways involved in cancer development and progression.

\section{Mir-221/222}

MiR-221 and miR-222 are both up-regulated in several glioma derived cell lines and in glioma samples (28). Mir-221 levels were found to rise particularly in high-grade gliomas with increased proliferation rates (38), suggesting it could represent a reliable prognostic marker. They are clustered within a $1-\mathrm{kb}$ genomic interval on chromosome $\mathrm{X}$, so they could be generated from the same primary transcript $(59,60)$.

Up-regulation and oncogenic role of these miRNAs in many tumors may account for their proliferation-specific expression, evidenced by their higher levels when cells enter cell cycle from quiescence. MiR-221 and miR-222 are up-regulated after growth factor stimulation of quiescent human glioblastoma cell proliferation, suggesting they could promote competency for cell proliferation (61). Two members of the Kip/Cip family of CDK inhibitors and key negative regulators of the cell cycle, p57 and p27, have been identified as putative direct targets of these miRNAs. According to this theory, the 3'-UTR of p57 harbors one site expected to be recognized by both miR-221 and miR-222, whereas the 3'-UTR of p27 contains two sites for both miRNAs. Transfection of both miR-221 and miR-222 greatly reduce the levels of p57 and p27 proteins, while downregulation of either microRNA 221 or 222 in glioblastoma cells caused an increase in p27 levels and enhanced expression of the luciferase reporter gene fused to the p27 3'-UTR. These 
results suggest that miR-221 and miR-222 could promote cell proliferation and S-phase entry together with further cooperative events and that miRNA 221 and 222 inhibition may be a potential therapeutic target to reduce the aggressive growth of glioblastoma by restoring normal levels of their target proteins $(61,62)$. The inverse correlation between mir-221/222 and p27 levels, the impairment of growth potential and the G1 to S shift in the cell cycle of glioma cells after inhibition of mir-221/222, were later confirmed by Zhang et al. They extended their study to in vivo trials and showed that miR-221/222 knocked-down through antisense oligonucleotides strongly reduced glioma subcutaneous mice xenografts growth through up regulation of p27 (63) and enhanced radiosensitivity of glioblastoma cell lines (64). Further evidence showed that knockdown of miR-221/222 induced a change of mitochondrial membrane potential and caspase-mediated apoptosis on glioblastoma cells. Indeed, mir-221/222 directly downregulate the proapoptotic protein PUMA (mediator of p53-associated apoptosis), which leads in turn to decrease $\mathrm{Bcl}-2$ and increase BAX (key regulators of mitochondrial apoptotic pathway); these results confirm the oncogenic role of mir-221/222 on glioblastoma (65).

A recent bioinformatic analysis revealed a panel of 70 genes potentially regulated by miR-221/222 and among them many key regulators of Akt signaling pathway. Ectopic overexpression of miR-221/222 increased glioma cell proliferation and invasion in vitro, induced glioma progression in a mouse model after subcutaneous injection of the tumor and resulted in activation of p-Akt, suggesting miR-221/222 could regulate glioma malignant phenotype through the activation of Akt pathway (66).

\section{Mir-34a}

Mir-34a, transcriptional target of p53 located within chromosome $1 \mathrm{p} 36$, has been proposed as a potential tumor suppressor. As many authors evidenced, it is downregulated and function as a tumor suppressor gene in many human cancers (67). MiR-34a is also downregulated in glioblastoma tissues and cell lines compared to normal brain tissues and is markedly reduced in p53-mutant cells compared to cells expressing wild-type p53 $(68,69)$. Downregulation of mir34a may be related to a range of molecular mechanisms such as deletion of chromosome 1p, which has been shown in 70-85\% of oligodendrogliomas and up to $30 \%$ of astrocytoma (70); p53 mutations, that are found in $30 \%$ of all gliomas irrespective of tumor grade (71); aberrant $\mathrm{CpG}$ methylation of the miR-34a promoter (72), though this mechanism has not been investigated in brain malignancies so far.

MiR-34a possesses hundreds of predicted mRNA targets which could mediate its inhibitory effects on tumor growth. A few of these have been experimentally verified and include oncogenes such as MYC, CCND1, CDK6, SIRT1 (67) and c-Met (73). It was shown to directly inhibit c-Met in glioma and medulloblastoma cells and Notch-1/Notch- 2 in glioma cells and stem cells by binding to the 3'-UTRs of their mRNA. Furthermore, mir-34a inversely correlates with c-Met, Notch1, Notch2 and CDK6 protein expression in glioma cells. Transfection of microRNA34a in brain tumor cells strongly inhibits cell proliferation, cell cycle progression, cell survival, cell invasion, and in vivo glioma xenograft growth but do not affect cell cycle or death when transfected to human astrocytes, which showed normal expression levels of microRNA 34a. Restoration of
c-Met or Notch-1 and Notch-2 expression by constructs lacking 3'-UTR regions partially reverted cell cycle arrest and apoptosis induced by miR-34a in glioma cells or stem cells, confirming the hypothesis that the antitumor effects of miR-34a are achieved via targeting of multiple oncogenes (68). Interestingly, mir-34a also affect glioma stem cell differentiation and growth (see below).

Luan et al, besides confirming the inhibitory effects of transfected mir-34a on glioma tumorigenesis, recently reported silent information regulator 1 (Sirt1) as a direct negative target of mir34a in glioma cell lines at a posttranscriptional level (69). Repression of Sirt1 by mir34a has been previously shown on human colon cancer cell lines (74) and confirmed in a recent report which showed that mir-34a plays an important role in the induction of senescence of endothelial progenitor cells via inhibiting Sirt1, thus impairing tumor angiogenesis (75). Sirt1 is a NAD-dependent deacetylase that regulates apoptosis in response to oxidative and genotoxic stress (76), and has recently been involved in tumorigenesis acting as an oncogene $(77,78)$. Taken together, these studies introduce mir-34a as a promising brain tumor therapeutic agent.

\section{Mir-128}

Mir-128, a brain enriched microRNA, is downregulated in glioma cell lines and tissue when compared to normal brain samples (79,80). Mir-128 overexpression decreased glioma cell proliferation in vitro and glioma xenograft growth in vivo, and is inversely correlated to Bmi-1 expression. Mir-128 directly targets and downregulates Bmi-1 (part of a polycomb silencing complex involved in differentiation and senescence through a modification of chromatin structure) by binding its 3'-UTR region (81) and leads to a concomitant overexpression of $\mathrm{p} 21^{\mathrm{CIP} 1}$ and a decrease in phosphorylated Akt (80). Bmi-1 expression is a critical factor of normal stem cell maintenance and glioblastoma self-renewal and loss of Bmi-1-mediated self-renewal of neural stem cells has been shown to be associated with upregulation of p2 $1^{\mathrm{CIP} 1}$ (82) and decreased Akt activation (83). Moreover, a depletion of stem cells by early adulthood in Bmi-1 knockdown mice has been reported (84). Consistently with these observations, miR-128 overexpression in human glioma neurosphere cultures possessing a glioma 'stem-like' cell phenotype, evidenced that miR-128 specifically blocked glioma self-renewal reducing neurosphere number and size. In conclusion, mir-128 downregulation is likely to enhance glioma tumorigenesis by promoting an undifferentiated phenotype and self renewing state through Bmi-1 increased expression (80). By bioinformatical analysis, E2F3a, a transcription factor involved in cell cycle progression (85), has been identified as a direct target of this miRNA. Indeed, Mir-128 and E2F3a levels are negatively correlated and mir-128 overexpression has similar inhibitory effects on proliferation of glioma cell lines as E2F3a knocking down Ectopic overexpression of E2F3a partially reversed the effects of mir-128, suggesting that mir-128 could exert its antitumor effects at least partially by inhibiting E2F3a expression. Mir-128 was recently found to inversely correlate to WHO glioma grade, being more intense in grade III and IV tumors when compared to grade II tumors and normal brain. Among its target genes angiopoietin-related protein 5 (ARP5) was identified with bioinformatical tools and then confirmed to be inversely correlated to mir-128 levels in glioblastoma cells and tissue and downregulated after ectopic 
overexpression of this microRNA (79). ARP5 seems to be a key regulator of cell proliferation, remodeling and regeneration (86) and could be a member of a group of genes regulated by mir-128 that coordinately contribute to glioma and GBM pathology (81).

\section{Mir-451}

Mir-451 was found to be upregulated in glioma samples compared to normal brain on microarray-based miRNAome profiling $(80,87)$, further confirmed by both qRT-PCR and in situ hybridization (88). MiR-451 showed a striking spatial distribution, with groups of positive cells concentrated around a subset of blood vessels. Moreover, high levels of mir-451 are correlated to a poor prognosis in glioma patients. Mir- 451 could regulate the balance of proliferation and migration in glioma cells in response to changes in glucose levels and metabolic stress. It regulates 5'-adenosine monophosphate activated protein kinase (AMPK) pathway (the major cellular sensor of energy availability) in response to glucose levels in glioma cells, through the modulation of the activity of its upstream activator LKB1 (89). Activation of LKB1 is a potent anti-proliferative signal, and also influences cell polarity, a process known to affect cell motility (90).

MiR-451 regulates LKB1 activity by directly targeting the 3'-UTR of CAB39, a component of the active LKB1complex, leading to a downregulation of CAB39 protein levels. Downregulation of mir-451 levels in response to glucose deprivation leads to intense activation of LKB1 and downstream pathways, allowing cells to survive metabolic stress and promoting cancer cell migration. Conversely, when glucose is sufficient, elevated miR-451 levels lead to reduced LKB1/AMPK pathway activation. This facilitates cell proliferation but makes cells more sensitive to glucose deprivation. Thus mir- 451 could be a key regulator of adaptive response of cancer cells to altered energy availability $(88,89)$.

In partial contrast with these studies a recent report found mir-451 to be downregulated in glioma cell lines. Transfection of mir-451 to glioma cell lines was able to inhibit cell growth, induced G0/G1 phase arrest, increased cell apoptosis and most notably diminished the invasive capacity of these cells as evidenced by transwell invasion assay. These tumor suppressive effects may be due to modulated expression of a panel of proteins including CyclinD1, p27, MMP 2/9 and Bcl-2, probably via regulation of the PI3K/AKT signaling pathway. Indeed, expression of Akt1 protein decreased after mir-451 transfection (91).

Gal et al found an upregulation of mir-451 in CD133 glioma non-stem cells in a comparative study with $\mathrm{CD} 133^{+}$cells . Furthermore. transfection of glioblastoma cells with mir-451, besides inhibiting tumor growth, disperses neurospheres (see below). This effect is more evident if combined to treatment with imatinib mesylate (92).

In conclusion, the controversial actions of mir-451 still need to be elucidated to establish its effective role in brain tumors.

\section{Mir-7}

Mir-7, a microRNA modulated during neural differentiation of embryonic stem cells (93), is a putative tumor suppressor gene in glioblastoma. It inhibits EGFR gene expression by directly binding its mRNA at 3'-UTR. Furthermore, microRNA-7 suppresses the activation of Akt pathway and reduces phosphoAkt levels by directly targeting its upstream regulators IRS-1 and IRS-2 in their 3'-UTRs (94). The inhibitory effects of mir-7 on EGFR signaling and on Akt activation were further confirmed by an independent group on multiple human cancer cell types. They also identified Raf1 as a direct target of miR-7 by microarray analysis, Western blot and luciferase reporter assays of glioblastoma cells transfected with miR-7 (95). Inhibition of Akt activation seems to occur independently of mir-7-mediated repression of EGFR pathway. Consistenly with these findings miRNA-7 was markedly downregulated in glioblastoma tissue when compared to normal brain. The proposed mechanism that explains the lower expression of this microRNA is a processing defect in generating pre-miR-7 from pri-miR-7 in glioblastoma. Pre-miRNA-7 transfection decreased viability and invasiveness of glioblastoma lines and glioblastoma derived stem cells and led to an increase in the sub-G0 apoptotic fraction, a decrease in the $\mathrm{S}$ fraction and determined a G2-M arrest, most likely by affecting EGFR and Akt pathways, which have an established key role in gliomagenesis (94). Indeed, EGFR is frequently amplified and highly expressed in glioblastomas (26). In a recent report mir-7 was also shown to directly inhibit p21-activated kinase 1 (Pak1) in non-brain cancer cells (96). Pak1 is a widely upregulated signaling kinase in multiple human cancers, and it is involved in the regulation of many signaling pathways, including EGFR and Akt, thus interfering with cell motility, proliferation, and apoptosis (97). Furthermore, in glioblastomas, PAK1 upregulation is a negative prognostic marker and its knockdown results in impaired cell invasion (98). Further studies are required to assess whether mir-7 has a role in inhibiting Pak1 also in glioblastomas and if this interaction could affect gliomagenesis and survival. However, these preliminary results suggest mir-7 could have a potential and promising therapeutic role in brain tumors.

\section{Mir-181}

Mir-181a and mir-181b are well known brain-enriched miRNAs (99). Downregulation of mir-181a and mir-181b was detected in both glioma samples and cell lines $(28,38,100)$. Shi et al identified for the first time a negative correlation between mir-181a levels and glioma grade. Furthermore, they showed that mir-181a and mir-181b act as tumor suppressor genes. Transfection of both these miRNAs on glioma cell lines results in cell growth inhibition, invasion reduction and apoptosis induction, miR-181b being more effective than miR-181a (100). In a recent microRNA expression profiling conducted on a set of 124 astrocytoma samples and 60 normal adjacent tissue samples by qRT-PCR, Zhi et al found that downregulation of miR-181b is significantly associated with poor patient survival independently of other clinicopathological factors. Thus, mir-181b has a great potential for being used as a diagnostic and prognostic marker and to better select patients for adjuvant therapy (39).

In a recent study MiR-181b and miR-181c downregulation was found to be significantly associated to a positive response to concomitant chemoradiotherapy with temozolomide in glioblastoma patients, suggesting they could be used as predictive factors for therapy efficacy (101). These results suggest that mir-181 function as tumor suppressor in human gliomas, but further studies are required to identificate and validate its targets in brain tumor cells. 


\section{Mir-124/137}

Mir-124 is a brain-enriched microRNA that accounts for approximately $25 \%$ of total brain microRNAs (102). It plays a key role in neurogenesis as it was shown to be upregulated during development of the rodent nervous system, and during neuronal differentiation of mouse embryonal stem cells $(103,104)$. Ectopic overexpression of miR-124 in the same cells enhance neuronal differentiation (105) by targeting multiple onthogenic pathways.

MicroRNA-124 and microRNA-137 are downregulated in anaplastic astrocytomas (WHO grade III) and glioblastoma multiforme (WHO grade IV) relative to non-neoplastic brain tissue (27-29) and their levels increase by 8 - to 20 -fold, respectively, when cultured mouse neural stem cells are deprived of growth factors (see below). Consequently, growth factor signaling could promote brain tumor formation through suppression of miR-124 and/or miR-137 expression and inhibition of neural stem cells/tumor stem cell differentiation. Transfection of micro-124 and microRNA-137 to neural stem cells and tumor-derived stem cells leads to induction of cellular markers of differentiation (increased expression of neuronal markers Tuj1 and MAP2, neuritic branching, lower GFAP positive cells), G1 cell cycle arrest and reductions of the expression of the cell cycle regulator CDK6, a direct target of both microRNAs. These changes are accompanied by reduced self-renewal and tumorigenicity. Overexpression of miR-124 or miR-137 also reduced the expression of phosphorylated RB, a downstream target of CDK6 (29). These results suggest that ectopic expression of microRNA-124 and microRNA-137 could represent a valid therapy for glioblastoma multiforme treatment inducing differentiation of tumor cells and cell cycle arrest.

\section{Mir-125}

MiR-125b is a brain-enriched microRNA which could represent a marker of neural specification as it is upregulated in mouse P19 embryonal carcinoma cells induced to develop into neurons $(104,106)$.

Mir-125b directly regulates $p 53$ expression by binding to the 3'-UTR. Ectopic overexpression of mir-125b in human neuroblastoma SH-SY5Y cells represses the endogenous levels of p53 protein and suppresses p53-mediated apoptosis, suggesting it could act as an oncogene (107). In a recent study Mir-125b was found to be downregulated in glioma cell lines after treatment with ATRA (all-trans-retinoic acid), a regulator of neural differentiation and proliferation. Ectopic overexpression of mir$125 \mathrm{~b}$ stimulated glioma cell proliferation, partially recovering the cell growth inhibition induced by ATRA treatment, while mir-125b knockdown promoted ATRA-mediated cell apoptosis. Furthermore, Bmf was identified as a direct target of miR-125b, and they are inversely correlated (108). Bmf interacts with the prosurvival Bcl-2 proteins, regulating cellular apoptotic pathways (109). Indeed, transfection with miR-125b increase BCL-2 levels in glioma cells, and expression of BCL-2 was significantly decreased when cells were transfected with miR-125b inhibitor. Thus, Bmf may play an important role in the process of miR$125 \mathrm{~b}$ influencing cell apoptosis (108).

Recently, Cortez et al identified mir-125a as a potential therapeutic target in glioblastoma. It was found to be downregulated in glioblastomas and particulary in glioma stem cells
$\mathrm{CD}_{133^{+}}$. Overexpression of mir-125a inhibits invasion properties of glioblastomas, probably through a direct downregulation of podoplanin (PDPN), a membrane sialo-glycoprotein related to invasion and malignancy (110).

\section{Mir-326}

Kefas et al evidenced a feedback loop between microRNA-326 and Notch pathway, frequently deregulated in gliomas. Notch-1 knockdown induced mir-326 upregulation in glioma stem cells and conversely, ectopic overexpression of mir-326 decreased Notch pathway members level and activity. Forced expression of mir-326 also inhibited cell proliferation, viability and invasiveness and induced apoptosis in both established and stem cell-like glioma lines: these effects are at least partially explained through downregulation of the Notch pathway. Moreover, it reduced tumorigenicity in mouse xenografts, an in vivo model of glioma. Together with the observation that mir-326 is downregulated in glioblastomas relative to normal brain, these findings suggest that miR-326 is a potential tumor suppressor gene in glioma cells and that reversing Notch/ miR-326 axis toward miR-326 prevalence appears to be a potential therapy for brain tumors (111).

\section{Mir-26a}

Mir-26a was detected to be up-regulated in high-grade gliomas using miRNA microarrays. MiR-26a is a direct negative regulator of PTEN and significantly represses PTEN expression by binding to its mRNA 3'-UTR site. MiR-26a overexpression was attributed to the amplification of miR-26a-2 locus (chromosome 12q), one of the two miR-26a loci present in the human genome (mir-26a-1 and miR-26a-2) and is correlated with monoallelic PTEN deletion. It was suggested a temporal sequence to the molecular evolution of miR-26a-amplified gliomas, with PTEN loss most likely preceding miR-26a-2 amplification and, concordantly, miR-26a overexpression in genetically engineered PTEN $^{+-}$mice precluded loss of their remaining PTEN allele. Amplification of mir-26a is likely to promote the silencing of the remaing PTEN transcript in PTEN ${ }^{+/}$tumors, event analogous to a loss of heterozygosity. Furthermore, in a murine glioma model, PTEN repression mediated by overexpression of miR-26a, enhanced de novo tumor formation. Akt pathway activation and suppression of its negative regulator PTEN (phosphatase and tensin homolog) are particularly important and frequently occur in glioma development (The Cancer Genome Atlas Research Network 2008). These observations document a new epigenetic mechanism for PTEN regulation in gliomagenesis, further highlighting that dysregulation of Akt signaling is crucial to the glioma development and could be modulated through manipulation of miRNA expression (87). Moreover, MiR-26a is a frequent target of the 12q13.3-14.1 amplicon that also contain CDK4 and CENTG1, two oncogenes that regulate the RB1 and PI3 kinase/AKT pathways, respectively. The presence of this amplification is negatively correlated to patient survival. PTEN, $\mathrm{RB} 1$, and MAP3K2/MEKK2 were detected as functional targets of mir-26a in glioblastoma. Ectopic overexpression of miR-26a increased GBM cell growth, decreased apoptosis and enhanced gliomagenesis in vivo. Thus, miR-26a decreases PTEN expression, activates AKT, and promotes tumor growth. 
Using human U87 GBM cells that lack functional PTEN, mir-26a overexpression increased cell growth and decreased apoptosis despite the absence of PTEN, most probably by downregulating, respectively, RB1 and MAP3K2, a gene that encodes MEKK2 (112). MEKK2 is a mitogen-activated protein kinase kinase involved in JNK activation pathway that promote apoptosis in GBM cells (113). In conclusion, miR-26a overexpression, collaboratively with the coamplified gene CENTG1, promotes tumor growth by inhibiting PTEN or RB1 pathways and decreases JNK-dependent apoptosis in GBM via MAP3K2/ MEKK2 inhibition.

\section{Mir-10b}

Mir-10b is upregulated in glioma samples and glioma cell lines compared to non-neoplastic brain tissues, and shows a direct correlation with tumor grade and with multifocal lesions on enhanced MRI. In addition, mRNA and protein expressions of $\mathrm{RhoC}$ and urokinasetype plasminogen activator receptor (UPAR), which are known to contribute to glioma invasion and migration, were correlated with mir-10b expression in gliomas, probably via inhibition of the translation of the mRNA encoding homeobox D10 (HOXD10), which in turn represses the expression of these genes (114). These results suggest that mir-10 could be involved in regulation of the invasion and migration abilities of gliomas.

\section{Mir-15b}

Mir-15b was shown to be elevated in a panel of glioma cell lines. Transfection of glioma cells with miR-15b significantly increased G0/G1 cells and decreased the percentage of cells in S phase, while inhibition of mir-15b increased G0/G1 cell amount. Thus, miR-15b regulates cell cycle progression in glioma cells by targeting cell cycle-related factors as CCNE1 (cyclin E1), a validated downstream target of mir-15b (115).

\section{Mir-146b}

Mir-146b, a microRNA found to be downregulated in human glioma tissue, could exert an antitumor activity by reducing the expression of a matrix metalloproteinase gene, MMP16, one of its direct downstream targets. Indeed, transfection of U373 glioma cells with miR-146b precursor decreased tumor cell migration and invasion, while inhibition of miR-146b by LNA modified anti-miR-146b produced the opposite effect, without affecting cell proliferation (116). Thus, mir-146b could function as a tumor suppressor gene by inhibiting glioma metastatic phenotype.

\section{Mir-296}

Recent studies support a role of mir-296 in promoting angiogenesis in gliomas. When brain microvascular endothelial cells were co-cultured with U87 glioma cells or when vascular endothelial growth factor (VEGF) was added to cultured human brain microvascular endothelial cells, miR-296 was upregulated. Moreover, mir-296 levels were higher in endothelial cells isolated from human brain tumors compared to normal brain endothelial cells. Downregulation of miR-296 in endothelial cells resulted in the inhibition of morphologic characteristics associated with angiogenesis and reduced angiogenesis in glioma xenografts in vivo. This probably happens through the downregulation of the hepatocyte growth factor-regulated tyrosine kinase substrate (HGS), a validated target of mir-296, thus leading to a reduced HGS-mediated degradation of the platelet derived growth factor receptor (PDGFR) and vascular endothelial growth factor receptor (VEGFR). This result points out an interesting feedback loop, where VEGF induces miR-296 expression, which in turn increases cell response to VEGF. Consequently, manipulating mir-296 expression, could enable to control a key step in cancer angiogenesis (117).

\section{Mir-29}

Mir29 ( $a, b$ and $c)$ is downregulated in wide range of solid tumors including neuroblastoma, sarcomas and brain tumors and is inversely correlated to the expression of $\mathrm{B} 7-\mathrm{H} 3$, its validated direct target. B7-H3 is an immune modulator which appears to be overexpressed in many human solid tumors and to inhibit natural killer cells and $\mathrm{T}$ cells. Modulation of this protein by mir-29 could have implications in reversing immune escape by solid tumors (118). More recently mir-29b was found to be significantly downregulated in glioblastoma samples and cells and $\mathrm{CD} 133^{+}$tumor stem cells. Forced overexpression of this miRNA inhibited invasion and proliferation and induced apoptosis in glioblastoma cells. Mir-29b as well mir-125a directly targets podoplanin (PDPN), a putative marker of neural stem cells, related to invasion and malignancy in glioblastoma (110). Taken together these results suggest that mir-29b is a tumor suppressor in gliomas and could represent a potential therapeutic target in glioblastoma.

\section{MiR-17-92 cluster}

MiR-17-92 cluster, located within the locus 13q31-q32, encloses five miRNAs (miR-92-1, miR-19a, miR-20a, miR-19b, miR$17-5 p$ ), which have been frequently involved in tumorigenesis. MiR-17-92 cluster expression declines during development and remain low in most adult tissues, but re-expression occurs in many human cancers $(119,120)$. This cluster was detected to be amplified in glioblastoma samples by array comparative genomic hybridization and in situ hybridization and overexpressed by real-time stem-loop RT-PCR. Furthermore, expression of miR-17-92 cluster is downregulated upon induction of differentiation of GBM spheroid cultures by using all-trans retinoic acid (ATRA). Induction of differentiation leads to deregulation of most of the key pathways associated with self-renewal such as insulin-like growth factor 1 signaling, vitamin D receptor/ retinoic acid $X$ receptor activation, Wnt/ $/$-catenin signaling and retinoic acid receptor activation. Inhibition of miR-17-92 cluster leads to decreased cell viability and decreased cell proliferation probably through a de-repression of CDKN1, E2F1, PTEN and CTGF which are upregulated. Particularly, connective tissue growth factor (CTGF) gene was shown to be a direct target of miR-17-92 in glioblastoma spheroids by luciferase reporter assays (121). CTGF binds vascular endothelial growth factor (VEGFA), which is a central mediator of angiogenesis (122), and inhibits VEGFA-induced angiogenesis (123). Conversely, VEGFA was shown to inhibit MiR-17-92 (124), thus explaining 
the concomitant downregulation of VEGFA and miR-17-92 upon induction of differentiation. In conclusion, the interaction between CTGF, VEGFA and miR-17-92 might have a key role in gliomagenesis by targeting multiple regulatory pathways (121).

\section{Let-7}

Let-7 functions as a tumor suppressor in many cancers (125) by silencing RAS and high mobility group AT-hook 2 (HMGA2) $(126,127)$, but has been only slightly investigated on gliomas. RAS signaling has a key role in glioma tumorigenesis, where it regulates cell growth, survival, and invasion (128). Moreover, RAS inhibition reduces gliomagenesis and migration properties of tumor cells $(129,130)$. Consistently with these findings, although let-7 expression is not downregulated in human glioblastoma tissues and cell lines, let-7 ectopic overexpression by transfection on U251 and U87 human glioblastoma cells, reduced in vitro proliferation and migration and also in vivo tumor growth after xenotransplantation into nude mice. Furthermore, let-7 miRNA reduced the expression of total RAS, N-RAS, and K-RAS in glioblastoma cells (131). These results suggest that let-7 miRNA is able to impair glioblastoma growth and cellular migration via RAS inhibition.

\section{MicroRNAs and tumor stem cells}

Solid tumors are highly heterogeneous as they consist of cancer cells with recruited vasculature, inflammatory cells and stromal elements (132). Recent studies demonstrate that many solid malignancies contain a small population of neoplastic cells called cancer stem cells (CSCs) with a great potential for sustained self-renewal and tumor initiation, propagation and repopulation (133), that could contribute to chemoresistance and tumor angiogenesis. Although the proper terminology of these cells remains controversial because of frequent confusion with common stem cells, the term CSCs is the most widely accepted because it recognizes they share with stem cells the ability of self-renewal and differentiation.

Glioma stem cells (GSCs) have been recently identified $(134,135)$. Two different methods are currently used to isolate GSCs from tumor samples: sorting cells for the expression of the surface antigen CD133 (136) or exploiting their ability to aggregate in neurospheres in vitro (135).

They express common neural stem cell (NSC) markers (CD133, Nestin, Musashi, and Sox2) and display multiple-lineage differentiation potential (astrocytes, oligodendrocytes and neurons) and a greater tumorigenic activity in rodent xenografts. GSCs also show an increased angiogenic potential through a higher expression of vascular endothelial growth factor (VEGF), a powerful pro-angiogenic factor. GSCs are strongly resistant to radiation (137) and chemotherapy $(138,139)$. Together with these data, the hypothesis was raised that gliomas originate and are maintained by this small population of GSCs. Consequently, the efficacy of tumor cytotoxic therapy and anti-angiogenic therapies, could be improved by direct targeting of cancer stem cells.

The role of microRNAs in self-renewal and differentiation has been recently established (140). Ablation of Dicer in mice causes defects in embryonic stem cells, cell-cycle and proliferation, leading to death in mice and complete loss of pluripotent stem cells $(141,142)$.
Many groups have previously observed the key role of microRNAs in neural stem cell development $(102,143)$. Adult neural stem cells are mostly concentrated in the subventricular zone and in the dentate gyrus and they are able to differentiate into neurons, astrocytes and oligodendrocytes (144) and to grow in aggregates called neurospheres (145). Increasing evidence shows that the expression profile of microRNAs in stem cells resemble those of cancer cells (146) and therefore the subpopulation of GSCs share several properties with NPCs (147).

A recent study by Lavon et al showed that glioma cell lines, as well as primary human gliomas, had a NPC-like miRNA expression signature (148). They confirmed the results of previous studies $(29,40)$, which showed a similar expression pattern of mir-21, mir-124, and mir-137 in gliomas and stem cells. Furthermore, they found that half of the miRNAs that share a similar expression in gliomas and NSCs are located in in 7 critical genomic regions involved in cancer development and prone to genetic or epigenetic alternations in many tumors $(7,149)$. Among them we mention the miR-17 family cluster that contains 3 miRNAs upregulated in gliomas and NPCs (mir-17-92, mir-106b-25, mir-106a); the mir-183-182 cluster, also upregulated in gliomas and NPCs; the large 7+46 bipartite miRNA cluster on chromosome 14 , as most of miRNAs located within this region have been shown to be downregulated in the same samples (148). This latter cluster is located within a region which shows a frequent loss of heterozygosity in glioblastomas $(150,151)$. Finally, mir302-367 cluster on chromosome 4q25 and mir371-373 cluster on chromosome 19q13, are upregulated in gliomas and NPCs. It is interesting to note that mir371-373 cluster has already been linked to tumorigenesis and cancer cell migration and invasion in previous studies $(152,153)$, and it epigenetically controls the expression of factors involved in maintenance of stem cell properties (154). Furthermore, mir-302 is a downstream target of Sox2, a transcription factor highly expressed in NSCs and GSCs, and it regulates cyclin D expression (155).

These data confirm the hypothesis that brain cancers arise from multipotent GSCs, thus explaining the phenotypic heterogeneity of tumors.

Many groups investigated the role of microRNAs in GSCs so far: in a first report Silber et al found that mir-124 and mir-137 are reduced in grade III and IV gliomas compared to normal brain (see above). Besides, transfection of these two miRNAs in neural stem cells and glioma cancer cell lines leads to induction of cellular markers of differentiation, G1 cell cycle arrest and reductions of CDK6, thus indicating a hypothetical tumor suppressor role of micro-124 and microRNA-137 in GSCs (29). As previously mentioned in this review, mir-128 was identified as a negative regulator of glioma self renewal when ectopically overexpressed on human glioma neurosphere cultures (80).

A recent analysis of the differential expression of miRNAs in the $\mathrm{CD}_{133^{+}}$and $\mathrm{CD} 133^{-}$populations of primary glioblastoma, showed that mir-451 is significantly downregulated in CD133 ${ }^{+}$ cells. Transfection of miR-451 inhibits proliferation and neurosphere formation in GSCs, highlighting that it can act as a tumor suppressor: two target sites for SMAD protein in the upstream promoter region of miR-451 have been found, leading to draw the conclusion that this miRNA is activated by SMAD pathway. Transfection of SMAD in GBM cells inhibited their growth, suggesting it could induce differentiation of glioma CD133+ 
stem cells through up-regulation of miR-451, thus reducing their tumorigenicity (92).

In conclusion, a stable and selective delivery of these miRNAs to GSCs could represent a great advance for brain tumor therapy.

Another neuronal microRNA, mir-125b, is required for stem cell fission, allowing them to bypass the G1/S checkpoint and making them insensitive to chemotherapy (156). It has been found to be significantly downregulated in $\mathrm{CD} 133^{+}$glioma stem cells compared to CD133 ones, leading to the hypothesis that it may be involved in cell differentiation. As expected, transfection of mir-125b to CD133+ cells, decreased the number of proliferating cells and induced G0-G1 arrest: this effect occurs through a mir-125b-dependent downregulation of CDC25A and CDK6, two cell cycle regulatory proteins (157). Moreover, miR-29b and miR-125a, are under-expressed in glioblastoma $\mathrm{CD} 133^{+}$cells compared with their counterpart CD133- cells (see above), suggesting a potential role for these microRNAs in regulation of signaling pathways related to maintenance of stem cell properties and self-renewal of cancer cells (110).

Some miRNAs could have a role in the regulation of key pathways of GSCs. We already mentioned above the existence of a regulatory feedback loop between the tumor suppressor mir-326 and Notch pathway, shifted towards a prevalence of Notch activity in brain tumor cells and GSCs (111) Recently, pyruvate kinase type M2 (PKM2) has been identified as a putative target of mir-326, as levels of PKM2 and mir-326 are inversely correlated in glioma cells. PKM2, highly expressed on cancer cells and GSCs, plays the role of mediator in mir-326 metabolic effects: experimental knockdown of this molecule led to an impairment of glioma invasiveness and clonogenicity and decreased ATP levels, suggesting that PKM2 could represent a valid target for glioma therapy (158).

Mir-34a, a tumor suppressor downregulated in gliomas and GSCs previously found to be involved in brain tumors development by targeting multiple pathways (see above), interestingly affects differentiation of GSCs. When transfected into GSCs, it decreased the expression of the stem cell markers CD133 and nestin and caused an higher immunostaining for astrocytes and oligodendrocytes markers (GFAP, claudin-11), besides modestly inhibiting several malignancy end-points (migration, survival, proliferation, cell cycle progression). Remarkably, miR-34a levels in glioma stem cells are significantly lower than in differentiated wild-type p53 glioma cell lines, suggesting that restoration of $\mathrm{miR}-34 \mathrm{a}$ expression for therapeutic purposes could achieve strong anti-tumor effects not only by targeting differentiated glioma cells, but also by inducing glioma stem cell differentiation (67).

\section{MicroRNAs in medulloblastoma}

Medulloblastoma (MB) is the most common brain malignancy observed in childhood (WHO grade IV) (159). It is an embryonal tumor of the cerebellum that originates from aberrant growth of cerebellar granule cell precursors, which, during development, reside in the external granule cell layer (160). Despite multimodal treatments (surgical resection, chemotherapy and/ or radiotherapy), the five-year survival rate of approximately $70 \%$ remains for standard risk medulloblastoma (161); highrisk patients have lower survival rates because of recurrence or dissemination within central nervous system (162). Moreover, survivors commonly have severe treatment-induced side effects that lead to long-term neurological, neuroendocrine, and social disabilities $(163,164)$. Although MBs are genetically and epigenetically heterogeneous, the presence of an isochromosome $17 \mathrm{q}$ (i17q) and disrupted development-related signalling pathways like Sonic Hehdgehog (SHH) and WNT, are the most frequent alterations in medulloblastoma (160).

Therefore, there is an urgent need for a deep understanding of the molecular carcinogenesis of medulloblastoma, so that future effective and low-toxicity targeted therapies can be made available.

Ferretti et al were the first to identify signatures of a set of 248 miRNAs in a panel of primary medulloblastomas and normal cerebellar controls using high throughput expression profiles. They showed different expression profiles between normal brain and tumor and between distinct tumor histotypes. In particular, they detected an upregulation of mir-21 and miR-17-92 cluster (miR-17-5p, miR-20a and miR-19a) and a downregulation of miR-128a/b, let-7, miR-124a, miR-103, miR-134, miR-138, miR-149, miR-181b, miR-9 and miR-125a, most of them previously reported to be dysregulated in other brain tumor cell lines or nervous system cancers (165). They potentially have a role in MB development: e.g., let-7 microRNAs has been shown to inhibit Ras oncogene expression (126), reported to be a key factor for MB metastatic behavior (166); miR-17-92 cluster cooperates with myc, frequently overexpressed in $\mathrm{MB}$, to induce neoplastic transformation $(165,167)$; miR-9 and miR-125a, both downregulated in $\mathrm{MB}$, are involved in cell proliferation and, when transfected into MB cells, promote apoptosis and impair anchorage-independent growth by downregulating the truncated isoform of the neurotropin receptor TrkC (t-TrkC). T-TrkC expression levels are higher in $\mathrm{MB}$, inversely correlate with miR-9 and miR-125a levels and are responsible of enhanced cell proliferation and worse prognosis. Furthermore, Ferretti et al detected a strong downregulation of mir-124 (165): this microRNA is associated with a neuronal differentiated phenotype, and its lower levels in $\mathrm{MB}$ are consistent with a dysregulation of differentiation in these tumors (168). Mir-9 and mir-124 have a common molecular target, REST/NRSF (RE1 silencing transcription factor/neuronrestrictive silencer factor) complex $(169,170)$. These observations suggest that Mir-9 and mir-124 could play an important role in cerebellar tumorigenesis as REST inactivation has been reported to inhibit tumor growth (171) and is overexpressed in many MBs (172). Consequently, a REST/mir-124 axis shifted towards a prevalence of REST activity, could block neuronal differentiation and promote neoplastic transformation $(173,174)$.

Mir-124 also modulates medulloblastoma growth by targeting CDK6, a key pro-proliferative factor overexpressed in $30 \%$ of medulloblastomas, which represents an adverse prognostic marker for clinical outcome $(168,175)$. The role of mir-124 in MB development was later confirmed by Li et al who additionally demonstrated that ectopic expression of mir-124 in medulloblastoma cell lines inhibits cell growth by directly targeting SLC16A1, a protein upregulated in MBs, that serve as a carrier to export lactic acid extracellularly, thus maintaining homeostasis of tumor cells, where aerobic glycolysis is known to be accelerated (176).

It is conceivable that a subgroup of miRNAs is differentially expressed in distinct tumor histotypes and could thereby 
help to identify distinct biological and clinical behaviour: e.g., upregualtion of miR-let7g, miR-106b, miR-191 and miR-19a and downregulation of miR-153 and miR-31 have been related to more aggressive tumor histotypes and poor clinical prognosis (165).

A more recent microarray analysis of microRNA signature in MBs, that partially confirmed the previous studies, focused on the role of miR-17, miR-100, miR-106b (upregulated in MBs) and miR-218 (downregulated). Among the putative target of the upregulated miRNAs they were identified some tumor suppressor genes: p53-binding protein 3, TOPORS, which cooperate with p53 for the inhibition of cell growth by cell cycle arrest; BAMBI, a negative regulator of TGF- $\beta$ signaling; BTG2, which promotes cerebellar neurogenesis and differentiation. At the same time, downregulation of miR-218 could account for an overexpression of the pro-oncogene EGFR, which activates MAPK pathway and CTNND2, which in turn encodes the gene of $\beta$-catenin that activates the APC/ Wnt signal transduction pathway and leads to tumor growth (177).

Hedgehog (Hh) patched (Ptch1) signalling pathway is a key regulator of the development of cerebellar granule cell progenitors and its constitutive activation makes cells susceptible of malignant transformation into medulloblastoma (178). Hh is a secreted protein that binds to the transmembrane receptor Ptch1 transducing an intracellular signal through the protooncogene Smoothened (Smo) to the downstream transcription factors Gli1, Gli2, and Gli3 (179).

The first study to identify microRNAs that target this pathway was published in 2008 by Ferretti et al. They found that miR-125b, miR-326 and miR-324-5p target and repress activator downstream components of the Hh signalling pathway (Smo and Gli1); consistent with these findings, $50 \%$ of MBs showed a downregulation of these miRNAs together with an overexpression of Gli1. Deletion of chromosome 17p, the most frequent mutation in medulloblastoma, could account for several genetic defects, including miR-324-5p, p53 and HIC1 tumor suppressors loss, which cooperate in Hh-dependent tumorigenesis: loss of these genes, together with other molecular events, contribute to a persistent hyperactivation of $\mathrm{Hh}$ signalling during cerebellar granule cell progenitors development, leading to higher proliferative activity and susceptibility to malignant MBs $(180,181)$.

Recently, Hedgehog signalling pathway has been identified as a target of miR-17-92 cluster. Indeed, miRNAs from the miR-17-92 cluster are specifically overexpressed in mouse MB models with specific initiating mutations in Ptch1 and in human MB subgroups with an activated SHH signaling pathway. To evaluate its oncogenic potential, miR-17-92 was retrovirally transduced into mouse granule neuron progenitors cells (GNPs) before orthotopic transplantation into immunocompromised mice. Interestingly, only cells with an $\mathrm{SHH}$ signaling defect $\left(\mathrm{Ptc}^{+-}\right)$developed MBs. Tumor cells from this model exhibited markers of activated SHH signaling as elevated Math1 and Gli1 mRNA levels, and lost expression of the wild-type Ptc allele, reinforcing the hypothesis of a functional link between the $\mathrm{SHH}$ pathway and this microRNA cluster (182). Using high-resolution SNP (single-nucleotide polymorphism) genotyping arrays and interphase fluorescence in situ hybridisation (iFISH) on human MB issue microarray, Northcott et al, identified recurrent, high-level amplification of miR-17-92 on chromosome 13q31.
Furthermore, a miRNAome profiling using miRNA microarrays performed in a group of 90 primary human medulloblastomas, revealed that miRNAs encoded by miR-17-92 polycistron are the most upregulated when compared to normal cerebellum, suggesting they play a key role in medulloblastoma pathogenesis. Besides the observation that miR-17-92 is most highly expressed in SHH-driven medulloblastomas, these authors showed that higher levels of miR-17-92 are also related to an overexpression of the oncogene MYC. Moreover, transfection of miR-17-92 maintains mouse CGNP cells in a proliferative state in the absence of $\mathrm{SHH}$, and synergizes with $\mathrm{SHH}$ to promote cell growth, while treatment of the same cells with $\mathrm{SHH}$ results in upregulation of miR-17-92, confirming that this cooperation is crucial in MB tumorigenesis (183).

Notch pathway plays a key role in regulating granule-cell progenitor differentiation and an increased copy number of Notch-2 was detected in $15 \%$ of medulloblastomas (184). Notch-1 and 2 have opposite effects on medulloblastoma growth since notch-1 inhibits and notch-2 promotes MB cells proliferation. Consistent with these findings, Notch-2 receptor transcripts are highly expressed in progenitor cell derived brain tumors such as medulloblastomas, whereas Notch-1 is almost undetectable (185).

Expression of the downstream effector of Notch, HES1, normally declines during neuronal differentiation, while persistent activation of this factor prevents differentiation of precursor cells (186). HES1 expression has been associated with worse clinical outcome in MBs (187). The cross-talk between SHH and Notch pathway has been confirmed by the finding that $\mathrm{SHH}$ treatment induces HES1 expression in GNPs cells (184).

In a recent in silico analysis, Garzia et al, identified mir-199-5p as capable of directly targeting and repress expression of HES1 in MB cell lines. Ectopic expression of this miRNA reduced MB cell proliferation, population expressing stem cell marker CD133 and xenograft tumor growth in mouse models. In a panel of 61 MB patients, they found that the expression of miR-199b-5p was significantly higher in non-metastatic than in metastatic samples and that miR-199b-5p levels are positively related to survival. Their studies also suggest that the documented downregulation of miR-199b-5p in metastatic tumors may be related to epigenetic silencing (188).

In a recent SNP-array based genome-wide analysis conducted on MB cell lines, subsequently confirmed by iFISH and PCR-based mapping, a novel region of amplification adjacent to the MYC locus on chromosome $8 \mathrm{q} 2$ was detected. One coding gene (KHDRBS3) and two genes encoding microRNAs (miR-30b, miR-30d) harboured by the $3 \mathrm{Mb}$ region of amplification, have been recognized as putative oncogenic targets whose expression is closely correlated with amplification status. Results suggest that these miRNAs species could play a crucial role in MB pathogenesis (189).

Venkataraman et al recently showed that several miRNAs known to be involved in CNS development, are downregulated in medulloblastoma cell line cultures and tissues. A specific one, miR-128a, is able to decrease tumor growth and proliferation if ectopically re-expressed on MB cells. Bmi-1 has been identified as a putative target of miR-128a, a critical factor in cerebellar development frequently upregulated in MBs. MiR-128a seems to normally downregulate Bmi-1 oncogene, leading to increased levels of p16, a cell cycle inhibitor. Furthermore, Bmi-1 could 
be involved in regulating reactive oxygen species by decreasing superoxide generation, thus leading to a lower redox state in cancer stem cells $(190,191)$; this event is known to be partially responsible of tumor resistance against common therapies (192). Hence, restoring normal redox state by re-expressing microRNA 128a (shown to induce premature senescence and increase the levels of p16 and intracellular superoxide generation by targeting Bmi-1), could be a useful strategy to improve the efficacy of cancer therapy (190).

Finally, mir-34a appeared to be a tumor suppressor gene also in medulloblastomas other than in glioblastomas. Indeed, transient transfection of miR-34a into medulloblastoma cell lines, strongly inhibited cell proliferation, cell cycle progression, cell survival and cell invasion most probably through a direct inhibition of c-Met (68).

\section{MicroRNAs in pituitary tumors}

Pituitary adenomas are benign and frequent neoplasms, accounting for about $15 \%$ of primary intracranial tumors (193). They can take origin from each of the five differentiated cell subtypes of the gland (somatotropes, lactotropes, corticotropes, thyrotropes, and gonadotropes) and they can be hormonesecreting or non-functioning. Despite their predominantly benign nature, they are associated with substantial morbidity through clinical syndromes of hyper or hypo-hormone secretion (amenorrea-galactorrea, acromegaly, Cushing disease, TSH-dependent hyperthyroidism, and hypopituitarism), associated or not to the compression of peri-sellar structures like optic chiasm and hypothalamus. The etiology of pituitary tumors is largely unknown and involves a wide range of factors such as hypotalamic dysfunction, gene mutations and familial risk (194).

Recent microarray data reported a possible role of microRNAs in the molecular pathogenesis of pituitary adenomas. The first connection between pituitary adenomas and microRNAs was established by Bottoni et al in 2005, that showed a downregulation of mir-15a and miR-16-1 in GH-secreting and in PRL-secreting adenomas compared to normal pituitary tissue. Furthermore, their expression is inversely correlated with tumor size. They probably act through a negative regulation of RARS (arginyl-tRNA synthetase), which is in turn upregulated in pituitary adenomas and modulates the expression of factors influencing pituitary tumor growth (195). Mir-15a and mir-16-1 are located within chromosome region $13 q 14$. Interestingly, loss of $13 q$ region of chromosome 13 was frequently detected in pituitary tumors, confirming that this region likely contains tumor suppressor genes (187).

In 2007 Bottoni et al explored the miRNAome of pituitary tumors by microarray. They found that 30 miRNAs are differentially expressed between normal pituitary gland and pituitary adenomas. Among them, miR-150, miR-152, miR-191, and miR-192 were found to be upregulated in pituitary adenomas, confirming that they are involved in cell growth, as was previously shown by Cheng et al (196). On the contrary, miR-132, miR-128a, miR-136, miR-16-1, and let-7 are downregulated. These findings support the hypothesis that miRNA-16-1 plays a key role in tumor growth (195), most probably by interacting with BCL2 (197), which is overexpressed in about one third of pituitary adenomas (198). MiRNAome could also function as a signature for specific histotypes of pituitary adenomas. Overexpression of miR-23a, miR-23b, and miR-24-2 and lower expression of mir-26b are more typical of GH-secreting and PRL-secreting adenomas (consistent with their common histological origin), differentiating them from non-functioning adenomas (NFA), characterized by mir-26 upregulation and miRNA-24-2 downregulation. Moreover, NFA express higher concentration of miR-137 and lower of miR-127, miR-129, miR-203, and miR-134 compared to GH-secreting adenomas. Finally, ACTH-secreting adenomas are defined by a strong expression of mir-30 cluster (miR-30a, miR-30b, miR-30c, and miR-30d), supporting the hypothesis that miRNAs could be useful diagnostic markers to distinguish pituitary tumor histotypes (199).

More recently, Amaral et al evaluated the expression of microRNAs in ACTH-secreting pituitary tumors: they found that let-7a, miR-21, miR-141, miR-143, miR-145, and miR-150, besides miR-15 and miR-16, are downregulated in corticotropinomas compared to normal pituitary tissue and that a lower expression of mir-141 is linked to a better chance of remission after surgery (200). Moreover, downregulation of Mir-143 could be involved in tumorigenesis by activating MAPK pathway via ERK5 (201).

Quian et al showed that let-7 expression is decreased in more than one third of pituitary adenomas and is related to higher tumor grade, thus it may act as a tumor suppressor. Levels of let-7 were found to be inversely correlated to HMGA2 expression (202), confirming some previous studies which showed that HMGA2 is repressed by let-7 $(127,203)$. High levels of HMGA2 have been detected in most types of pituitary adenomas $(204,205)$ and they are significantly associated with tumor grade, extent of invasion, tumor size and Ki-67 proliferation index, probably through regulation of E-cadherin, E2F1, cyclin A, and p53 expression. Accordingly, let-7 may be useful as a novel anticancer agent in the future (202).

Arecent study on the role of miRNAs in NFAs and GH-secreting pituitary tumors was performed by Butz et al, showing that a group of miRNAs (miR-128a, miR-155, and miR-516a-3p) targets the 3'-untranslated region of Weel, a nuclear protein kinase that acts as a tumor suppressor, and which was found to be significantly decreased in pituitary tumor samples (206).

\section{Conclusion and future perspectives}

The important role that miRNAs play in cancer development and progression is becoming increasingly clear. Spreading studies on this field are revealing a new class of potential diagnostic/prognostic factors as well as therapeutic targets and tools. MicroRNA expression profiling could help in distinguishing specific cancer from normal tissue and even highly from poorly differentiated tumors (207).

LNA anti-miRNAs (modified antisense single-stranded oligonucleotide inhibiting the expression of a specific mRNA) and antagomirs (chemically modified and cholesterol-conjugated single-stranded oligonucleotide specifically designed to inhibit miRNAs) for systemic delivery were unable to transfer suitable amounts of molecules to the brain. Several strategies to overcome the actual problems in miRNA delivery to brain are now under development. The special issue in delivering therapies to brain is the blood-brain-barrier (BBB), which protects brain from pathogens and toxins and is very hard to penetrate. Although disruption of the BBB in the proximity of tumors during advanced stages 
could enable to manage a conventional systemic microRNAbased therapy, for most tumors, it will be necessary to use local delivery techniques or develop new advanced systemic delivery strategies. Among the former we mention intrathecal delivery and the promising convection-enhanced delivery (CED), a postsurgical technique which consists in a prolonged low-pressure infusion via catheter within the resected tumor cavity. Among the most exploited systemic delivery strategies, viruses encoding miRNAs/inhibitors or liposomal nanoparticles for targeted delivery, have an outstanding role. On the opposite side, tumorsuppressive miRNAs may be targeted by replacement with miRNA mimetics or a miRNA-based delivery therapy could be used to enhance radio or chemo-sensitivity of brain tumors (208-210).

Furthermore, a very recent investigation showed that microRNAs can be transferred from rat 9L gliosarcoma cells and human U87-MG glioma cells that express a specific miRNA to non-expressing cells, most probably through gap junction communication between the co-cultured cells. This observation shows that transferred microRNAs are able to induce targeted inhibition of protein expression in acceptor adjacent cells and could have further implications for a deeper understanding of tumorgenesis and progression, as well as for the development of novel miRNA-based anti-tumor therapies (211).

In conclusion, the future challenge will be to extend all these promising discoveries into effective clinical benefits for patients suffering of these devastating cancers.

\section{References}

1. Bartel DP: MicroRNAs: target recognition and regulatory functions. Cell 136: 215-233, 2009.

2. Behm-Ansmant I, Rehwinkel J, Doerks T, Stark A, Bork P and Izaurralde E: mRNA degradation by miRNAs and GW182 requires both CCR4:NOT deadenylase and DCP1:DCP2 decapping complexes. Genes Dev 20: 1885-1898, 2006.

3. Wu L, Fan J and Belasco JG: MicroRNAs direct rapid deadenylation of mRNA. Proc Natl Acad Sci USA 103: 4034-4039, 2006

4. Standart N and Jackson RJ: MicroRNAs repress translation of m7Gpppcapped target mRNAs in vitro by inhibiting initiation and promoting deadenylation. Genes Dev 21: 1975-1982, 2007.

5. Vasudevan S, Tong Y and Steitz JA: Switching from repression to activation: microRNAs can up-regulate translation. Science 318: 1931-1934, 2007

6. Place RF, Li LC, Pookot D, Noonan EJ and Dahiya R: MicroRNA373 induces expression of genes with complementary promoter sequences. Proc Natl Acad Sci USA 105: 1608-1613, 2008.

7. Zhang L, Huang J, Yang N, Greshock J, Megraw MS, Giannakakis A,Liang S, Naylor TL, Barchetti A, Ward MR, YaoG, Medina A, O'Brien-Jenkins A, Katsaros D, Hatzigeorgiou A, Gimotty PA, Weber BL and Coukos G: microRNAs exhibit high frequency genomic alterations in human cancer. Proc Natl Acad Sci USA 103: 9136-9141, 2006

8. Bartels CL and Tsongalis GJ: MicroRNAs: novel biomarkers for human cancer. Clin Chem 5: 623-631, 2009.

9. Haase AD, Jaskiewicz L, Zhang H, Lainé S, Sack R, Gatignol A and Filipowicz W: TRBP, a regulator of cellular PKR and HIV-1 virus expression, interacts with Dicer and functions in RNA silencing. EMBO Rep 6: 961-967, 2005.

10. Diederichs $S$ and Haber DA: Dual role for argonautes in microRNA processing and posttranscriptional regulation of microRNA expression. Cell 131: 1097-1108, 2007.

11. Lewis BP, Burge CB and Bartel DP: Conserved seed pairing, often flanked by adenosines, indicates that thousands of human genes are microRNA targets. Cell 120: 15-20, 2005.

12. Friedman RC, Farh KK, Burge CB and Bartel DP: Most mammalian mRNAs are conserved targets of microRNAs. Genome Res 19: 92-105, 2009.
13. Yoo AS, Staahl BT, Chen L and Crabtree GR: MicroRNA-mediated switching of chromatin-remodelling complexes in neural development. Nature 460: 642-646, 2009.

14. Calin GA and Croce CM: MicroRNA signatures in human cancer. Nat Rev Cancer 6: 857-866, 2006.

15. Calin GA, Dumitru CD, Shimizu M, Bichi R, Zupo S, Noch E, Aldler H, Rattan S, Keating M, Rai K, Rassenti L, Kipps T, Negrini M, Bullrich F and Croce CM: Frequent deletions and down-regulation of micro-RNA genes miR15 and miR16 at 13q14 in chronic lymphocytic leukemia. Proc Natl Acad Sci USA 99: 15524-15529, 2002.

16. Visone R and Croce CM: MiRNAs and cancer. Am J Pathol 174: 1131-1138, 2009.

17. Bullrich F, Fujii H, Calin G, Mabuchi H, Negrini M, Pekarsky Y, Rassenti L, Alder H, Reed JC, Keating MJ, Kipps TJ and Croce CM: Characterization of the 13q14 tumor suppressor locus in CLL: identification of ALT1, an alternative splice variant of the LEU2 gene. Cancer Res 61: 6640-6648, 2001.

18. Ruan K, Fang X and Ouyang G: MicroRNAs: novel regulators in the hallmarks of human cancer. Cancer Lett 285: 116-126, 2009.

19. Esquela-Kerscher A and Slack FJ: Oncomirs-microRNAs with a role in cancer. Nat Rev Cancer 6: 259-269, 2006.

20. Calin GA, Ferracin M, Cimmino A, et al: MicroRNA signature associated with prognosis and progression in chronic lymphocytic leukemia. N Engl J Med 353: 1793-1801, 2005.

21. Stupp R, Mason WP, van den Bent MJ, Weller M, Fisher B, Taphoorn MJ, Belanger K, Brandes AA, Marosi C, Bogdahn U, Curschmann J, Janzer RC, Ludwin SK, Gorlia T, Allgeier A, Lacombe D, Cairncross JG, Eisenhauer E and Mirimanoff RO: European Organisation for Research and Treatment of Cancer Brain Tumor and Radiotherapy Groups; National Cancer Institute of Canada Clinical Trials Group. Radiotherapy plus concomitant and adjuvant temozolomide for glioblastoma. N Engl J Med 352: 987-996, 2005.

22. CBTRUS, 2008 CBTRUS, Statistical report: Primary Brain Tumors in the United States, 2000-2004, 2008.

23. Louis DN, Ohgaki H, Wiestler OD, Cavenee WK, Burger PC, Jouvet A, Scheithauer BW and Kleihues P: The 2007 WHO classification of tumours of the central nervous system. Acta Neuropathol 114: 97-109, 2007.

24. Maher EA, Furnari FB, Bachoo RM, Rowitch DH, Louis DN, Cavenee WK and De Pinho RA: Malignant glioma: genetics and biology of a grave matter. Genes Dev 15: 1311-1333, 2001.

25. Nieder C, Adam M, Molls M and Grosu AL: Therapeutic options for recurrent high-grade glioma in adult patients: recent advances. Crit Rev Oncol Hematol 60: 181-193, 2006.

26. FurnariFB,Fenton T,BachooRM,Mukasa A,StommelJM,Stegh A, Hahn WC, Ligon KL, Louis DN, Brennan C, Chin L, De Pinho RA and Cavenee WK: Malignant astrocytic glioma: genetics, biology, and paths to treatment. Genes Dev 21: 2683-2710, 2007.

27. Chan JA, Krichevsky AM and Kosik KS: MicroRNA-21 is an antiapoptotic factor in human glioblastoma cells. Cancer Res 65: 6029-6033, 2005.

28. Ciafrè SA, Galardi S, Mangiola A, Ferracin M,Liu CG, Sabatino G, Negrini M, Maira G, Croce CM and Farace MG: Extensive modulation of a set of microRNAs in primary glioblastoma. Biochem Biophys Res Commun 334: 1351-1358, 2005.

29. Silber J, Lim DA, Petritsch C, Persson AI, Maunakea AK, Yu M, Vandenberg SR, Ginzinger DG, James CD, Costello JF, Bergers G, Weiss WA, Alvarez-Buylla A and Hodgson JG: miR-124 and miR-137 inhibit proliferation of glioblastoma multiforme cells and induce differentiation of brain tumor stem cells. BMC Med 6: 14, 2008.

30. Nelson PT, Baldwin DA, Kloosterman WP, Kauppinen S, Plasterk RH and Mourelatos Z: RAKE and LNA-ISH reveal microRNA expression and localization in archival human brain. RNA 12: 187-191, 2006.

31. Liu T, Papagiannakopoulos T, Puskar K, Qi S, Santiago F, Clay W, Lao K, Lee Y, Nelson SF, Kornblum HI, Doyle F, Petzold L, Shraiman B and Kosik KS: Detection of a microRNA signal in an in vivo expression set of mRNAs. PLoS One 2: 804, 2007.

32. Kapsimali M, Kloosterman WP, De Bruijn E, Rosa F, Plasterk RH and Wilson SW: MicroRNAs show a wide diversity of expression profiles in the developing and mature central nervous system. Genome Biol 8: 173, 2007.

33. Zhao JJ, Hua YJ, Sun DG, Meng XX, Xiao HS and Ma X: Genome-wide microRNA profiling in human fetal nervous tissues by oligonucleotide microarray. Childs Nerv Syst 22: 1419-1425, 2006. 
34. Nass D, Rosenwald S, Meiri E, Gilad S, Tabibian-Keissar H, Schlosberg A, Kuker H, Sion-Vardy N, Tobar A, Kharenko O, Sitbon E, Lithwick Yanai G, Elyakim E, Cholakh H, Gibori H, Spector Y, Bentwich Z, Barshack I and Rosenfeld N: MiR-92b and miR $-9 / 9^{*}$ are specifically expressed in brain primary tumors and can be used to differentiate primary from metastatic brain tumors. Brain Pathol 19: 375-383, 2009.

35. Rao SA, Santosh V and Somasundaram K: Genome-wide expression profiling identifies deregulated miRNAs in malignant astrocytoma. Mod Pathol 23: 1404-1417, 2010.

36. Cho W.C: Oncomirs: the discovery and progress of micrornas in cancers. Mol Cancer 6: 60, 2007.

37. Si ML, Zhu S, Wu H, Lu Z, Wu F and Mo YY: miR-21-mediated tumor growth. Oncogene 26: 2799-2803, 2007.

38. Conti A, Aguennouz M, La Torre D, Tomasello C, Cardali S, Angileri FF, Maio F, Cama A, Germanò A, Vita G and Tomasello F: miR-21 and 221 upregulation and miR-181b downregulation in human grade II-IV astrocytic tumors. J Neurooncol 93: 325-332, 2009.

39. Zhi F, Chen X, Wang S, Xia X, Shi Y, Guan W, Shao N, Qu H, Yang C, Zhang Y, Wang Q, Wang R, Zen K, Zhang CY, Zhang J and Yang Y: The use of hsa-miR-21, hsa-miR-181b and hsa-miR106a as prognostic indicators of astrocytoma. Eur J Cancer 46: $1640-1649,2010$

40. Gabriely G, Wurdinger T, Kesari S, Esau CC, Burchard J, Linsley PS and Krichevsky AM: MicroRNA 21 promotes glioma invasion by targeting matrix metalloproteinase regulators. Mol Cell Biol 28: 5369-5380, 2008.

41. Malzkorn B, Wolter M, Liesenberg F, Grzendowski M, Stühler K, Meyer HE and Reifenberger G: Identification and functional characterization of microRNAs involved in the malignant progression of gliomas. Brain Pathol 20: 539-550, 2010.

42. Corsten MF, Miranda R, Kasmieh R, Krichevsky AM, Weissleder R and Shah K: MicroRNA-21 knockdown disrupts glioma growth in vivo and displays synergistic cytotoxicity with neural precursor cell delivered S-TRAIL in human gliomas. Cancer Res 67: 8994-9000, 2007.

43. Zhou X, Zhang J, Jia Q, Ren Y, Wang Y, Shi L, Liu N, Wang G, $\mathrm{Pu}$ P, You Y and Kang C: Reduction of miR-21 induces glioma cel apoptosis via activating caspase 9 and 3. Oncol Rep 24: 195-201, 2010.

44. Shi L, Cheng Z,Zhang J, Li R, You Y and Fu Z: The mechanism of apoptosis in human U87 glioma cells induced by miR-21 antisense oligonucleotide. Zhonghua Yi Xue Yi Chuan Xue Za Zhi 25 : 497-501, 2008

45. Papagiannakopoulos T, Shapiro A and Kosik KS: MicroRNA-21 targets a network of key tumor-suppressive pathways in glioblastoma cells. Cancer Res 68: 8164-8172, 2008.

46. Chen Y, Liu W, Chao T, Zhang Y, Yan X, Gong Y, Qiang B, Yuan J, Sun M and Peng X: MicroRNA-21 down-regulates the expression of tumor suppressor PDCD4 in human glioblastoma cell T98G. Cancer Lett 272: 197-205, 2008.

47. Meng F, Henson R, Wehbe-Janek H, Ghoshal K, Jacob ST and Patel T: MicroRNA-21 regulates expression of the PTEN tumor suppressor gene in human hepatocellular cancer. Gastroenterology 133: 647-658, 2007.

48. Ruan J, Chen H, Kurgan L, Chen K, Kang C and Pu P: HuMiTar: a sequence-based method for prediction of human microRNA targets. Algorithms Mol Biol 3: 16, 2008.

49. Endersby R and Baker SJ: PTEN signaling in brain: neuropathology and tumorigenesis. Oncogene 27: 5416-5430, 2008.

50. Leslie NR and Downes CP: PTEN: The down side of PI 3-kinase signalling. Cell Signal 14: 285-295, 2002.

51. Zhou X, Ren Y, Moore L, Mei M, You Y, Xu P, Wang B, Wang G, Jia Z, Pu P, Zhang W and Kang C: Downregulation of miR-21 inhibits EGFR pathway and suppresses the growth of human glioblastoma cells independent of PTEN status. Lab Invest 90: 144-155, 2010

52. Shi L, Chen J, Yang J, Pan T, Zhang S and Wang Z: MiR-21 protected human glioblastoma U87MG cells from chemotherapeutic drug temozolomide induced apoptosis by decreasing Bax/Bcl-2 ratio and caspase-3 activity. Brain Res 1352: 255-264, 2010.

53. Li Y, Li W, Yang Y, Lu Y, He C, Hu G, Liu H, Chen J, He J and Yu H: MicroRNA-21 targets LRRFIP1 and contributes to VM-26 resistance in glioblastoma multiforme. Brain Res 1286: 13-18, 2009.

54. Lee SY, Lee SY and Choi Y: TRAF-interacting protein (TRIP): a novel component of the tumor necrosis factor receptor (TNFR)- and CD30-TRAF signaling complexes that inhibits TRAF2-mediated NF-kappaB activation. J Exp Med 185: 1275-1285, 1997.
55. Nakanishi $\mathrm{C}$ and Toi M: Nuclear factor-kappaB inhibitors as sensitizers to anticancer drugs. Nat Rev Cancer 5: 297-309, 2005

56. Wang CY, Cusack JC Jr, Liu R and Baldwin AS Jr: Control of inducible chemoresistance: enhanced anti-tumor therapy through increased apoptosis by inhibition of NF-kappaB. Nat Med 5: 412-417, 1999.

57. Ren Y, Kang CS, Yuan XB, Zhou X, Xu P, Han L, Wang GX, Jia Z, Zhong Y, Yu S, Sheng J and Pu PY: Co-delivery of as-miR-21 and 5-FU by poly(amidoamine) dendrimer attenuates human glioma cell growth in vitro. J Biomater Sci Polym Ed 21: 303-314, 2010.

58. Ohno M, Natsume A, Kondo Y, Iwamizu H, Motomura K, Toda H, Ito $\mathrm{M}$, Kato T and Wakabayashi T: The modulation of microRNAs by type I IFN through the activation of signal transducers and activators of transcription 3 in human glioma. Mol Cancer Res 7: 2022-2030, 2009

59. He L, Thomson JM, Hemann MT, Hernando-Monge E, Mu D, Goodson S, Powers S, Cordon-Cardo C, Lowe SW, Hannon GJ and Hammond SM: A microRNA polycistron as a potential human oncogene. Nature 435: 828-833, 2005.

60. Lee EJ, Gusev Y, Jiang J, Nuovo GJ, Lerner MR, Frankel WL, Morgan DL, Postier RG, Brackett DJ and Schmittgen TD: Expression profiling identifies microRNA signature in pancreatic cancer. Int J Cancer 120: 1046-1054, 2007.

61. Medina R, Zaidi SK, Liu CG, Stein JL, van Wijnen AJ, Croce CM and Stein GS: MicroRNAs 221 and 222 bypass quiescence and compromise cell survival. Cancer Res 68: 2773-2780, 2008.

62. Gillies JK and Lorimer IA: Regulation of $\mathrm{p} 27^{\mathrm{Kipl}}$ by miRNA 221/222 in glioblastoma. Cell Cycle 6: 2005-2009, 2007.

63. Zhang C, Kang C, You Y, Pu P, Yang W, Zhao P, Wang G, Zhang A, Jia Z, Han L and Jiang H: Co-suppression of miR-221/222 cluster suppresses human glioma cell growth by targeting p27(kip1) in vitro and in vivo. Int J Oncol 34: 1653-1660, 2009.

64. Zhang C, Wang G, Kang C, Du Y and Pu P: Up-regulation of p27(kip1) by miR-221/222 antisense oligonucleotides enhances the radiosensitivity of U251 glioblastoma. Zhonghua Yi Xue Yi Chuan Xue Za Zhi 26: 634-638, 2009.

65. Zhang CZ, Zhang JX, Zhang AL, Shi ZD, Han L, Jia ZF, Yang WD, Wang GX, Jiang T, You YP, Pu PY, Cheng JQ and Kang CS: MiR-221 and miR-222 target PUMA to induce cell survival in glioblastoma. Mol Cancer 9: 229, 2010.

66. Zhang J, Han L, Ge Y, Zhou X, Zhang A, Zhang C, Zhong Y, You Y, Pu P and Kang C: miR-221/222 promote malignant progression of glioma through activation of the Akt pathway. Int J Oncol 36: 913-920, 2010.

67. Guessous F, Zhang Y, Kofman A, Catania A, Li Y, Schiff D, Purow B and Abounader R: MicroRNA-34a is tumor suppressive in brain tumors and glioma stem cells. Cell Cycle 9: 1031-1036, 2010.

68. Li Y, Guessous F, Zhang Y, Dipierro C, Kefas B, Johnson E, Marcinkiewicz L, Jiang J, Yang Y, Schmittgen TD, Lopes B, Schiff D, Purow B and Abounader R: MicroRNA-34a inhibits glioblastoma growth by targeting multiple oncogenes. Cancer Res 69: 7569-7576, 2009.

69. Luan S, Sun L and Huang F: MicroRNA-34a: a novel tumor suppressor in p53-mutant glioma cell line U251. Arch Med Res 41: 67-74, 2010

70. Barbashina V, Salazar P, Holland EC, Rosenblum MK and Ladanyi M: Allelic losses at 1p36 and 19q13 in gliomas: correlation with histologic classification, definition of a $150-\mathrm{kb}$ minimal deleted region on 1p36, and evaluation of CAMTA1 as a candidate tumor suppressor gene. Clin Cancer Res 11: 1119-1128, 2005

71. Zupanska A and Kaminska B: The diversity of p53 mutations among human brain tumors and their functional consequences. Neurochem Int 40: 637-645, 2002.

72. Lodygin D, Tarasov V, Epanchintsev A, Berking C, Knyazeva T, Körner H, Knyazev P, Diebold J and Hermeking H: Cell inactivation of miR-34a by aberrant $\mathrm{CpG}$ methylation in multiple types of cancer. Cycle 7: 2591-2600, 2008.

73. Yan D, Zhou X, Chen X, Hu DN, Dong XD, Wang J, Lu F, Tu L and Qu J: MicroRNA-34a inhibits uveal melanoma cell proliferation and migration through downregulation of c-Met. Invest Ophthalmol Vis Sci 50: 1559-1565, 2009.

74. Yamakuchi M, Ferlito M and Lowenstein CJ: miR-34a repression of SIRT1 regulates apoptosis. Proc Natl Acad Sci USA 105: 13421-13426, 2008.

75. Zhao T, Li J and Chen AF: MicroRNA-34a induces endothelial progenitor cell senescence and impedes its angiogenesis via suppressing silent information regulator 1 . Am J Physiol Endocrinol Metab 299: E110-E116, 2010. 
76. Haigis MC and Guarente LP: Mammalian sirtuins-emerging roles in physiology, aging, and calorie restriction. Genes Dev 20: 2913-2921, 2006.

77. Huffman DM, Grizzle WE, Bamman MM, Kim JS, Eltoum IA, Elgavish A and Nagy TR: SIRT1 is significantly elevated in mouse and human prostate cancer. Cancer Res 67: 6612-6618, 2007.

78. Yeung F, Hoberg JE, Ramsey CS, Keller MD, Jones DR, Frye RA and Mayo MW: Modulation of NF-kappaB-dependent transcription and cell survival by the SIRT1 deacetylase. EMBO J 23: 2369-2380, 2004.

79. Zhang Y, Chao T, Li R, Liu W, Chen Y, Yan X, Gong Y, Yin B, Liu W, Qiang B, Zhao J, Yuan J and Peng X: MicroRNA-128 inhibits glioma cells proliferation by targeting transcription factor E2F3a. J Mol Med 87: 43-51, 2009.

80. Godlewski J, Nowicki MO, Bronisz A, Williams S, Otsuki A Nuovo G, Raychaudhury A, Newton HB, Chiocca EA and Lawler S: Targeting of the Bmi-1 oncogene/stem cell renewal factor by microRNA-128 inhibits glioma proliferation and selfrenewal. Cancer Res 68: 9125-9130, 2008.

81. Cui JG, Zhao Y, Sethi P,Li YY, Mahta A, Culicchia F and Lukiw WJ Micro-RNA-128 (miRNA-128) down-regulation in glioblastoma targets ARP5 (ANGPTL6), Bmi-1 and E2F-3a, key regulators of brain cell proliferation. J Neurooncol 98: 297-304, 2010.

82. Fasano CA, Dimos JT, Ivanova NB, Lowry N, Lemischka IR and Temple S: shRNA knockdown of Bmi-1 reveals a critical role for p21-Rb pathway in NSC self-renewal during development. Cell Stem Cell 1: 87-99, 2007.

83. Guo WJ, Zeng MS, Yadav A, Song LB, Guo BH, Band V and Dimri GP: Mel-18 acts as a tumor suppressor by repressing Bmi-1 expression and down-regulating Akt activity in breast cancer cells. Cancer Res 67: 5083-509, 2007.

84. Sparmann A and van Lohuizen M: Polycomb silencers control cell fate, development and cancer. Nat Rev Cancer 6: 846-856, 2006.

85. Iaquinta PJ and Lees JA: Life and death decisions by the E2F transcription factors. Curr Opin Cell Biol 19: 649-657, 2007

86. Oike Y, Yasunaga K, Ito Y, Matsumoto S, Maekawa H, Morisada T, Arai F, Nakagata N, Takeya M, Masuho Y and Suda T: Angiopoietin-related growth factor (AGF) promotes epidermal proliferation, remodeling, and regeneration. Proc Natl Acad Sci USA 100: 9494-9499, 2003

87. Huse JT, Brennan C, Hambardzumyan D, Wee B, Pena J, Rouhanifard SH, Sohn-Lee C, Le Sage C, Agami R, Tuschl T and Holland EC: The PTEN-regulating microRNA miR-26a is amplified in high-grade glioma and facilitates gliomagenesis in vivo. Genes Dev 23: 1327-1337, 2009

88. Godlewski J, Bronisz A, Nowicki MO, Chiocca EA and Lawler S: MicroRNA-451: a conditional switch controlling glioma cell proliferation and migration. Cell Cycle 9: 2742-2748, 2010.

89. Godlewski J, Nowicki MO, Bronisz A, Nuovo G, Palatini J, De Lay M, Van Brocklyn J, Ostrowski MC, Chiocca EA and Lawler SE: MicroRNA-451 regulates LKB1/AMPK signaling and allows adaptation to metabolic stress in glioma cells. Mol Cell 37: 620-632, 2010.

90. Alessi DR, Sakamoto K and Bayascas JR: LKB1-dependent signaling pathways. Annu Rev Biochem 75: 137-163, 2006.

91. Nan Y, Han L, Zhang A, Wang G, Jia Z, Yang Y, Yue X, Pu P, Zhong Y and Kang C: MiRNA-451 plays a role as tumor suppressor in human glioma cells. Brain Res 1359: 14-21, 2010.

92. Gal H, Pandi G, Kanner AA, Ram Z, Lithwick-Yanai G, Amariglio N, Rechavi G and Givol D: MIR-451 and Imatinib mesylate inhibit tumor growth of glioblastoma stem cells. Biochem Biophys Res Commun 376: 86-90, 2008.

93. Chen H, Shalom-Feuerstein R, Riley J, Zhang SD, Tucci P, Agostini M, Aberdam D, Knight RA, Genchi G, Nicotera P, Melino G and Vasa-Nicotera M: miR-7 and miR-214 are specifically expressed during neuroblastoma differentiation, cortical development and embryonic stem cells differentiation, and control neurite outgrowth in vitro. Biochem Biophys Res Commun 394: 921-927, 2010

94. Kefas B, Godlewski J, Comeau L, Li Y, Abounader R, Hawkinson M, Lee J, Fine H, Chiocca EA, Lawler S and Purow B: microRNA-7 inhibits the epidermal growth factor receptor and the Akt pathway and is down-regulated in glioblastoma. Cancer Res 68: 3566-3572, 2008.

95. Webster RJ, Giles KM, Price KJ, Zhang PM, Mattick JS and Leedman PJ: Regulation of epidermal growth factor receptor signaling in human cancer cells by microRNA-7. J Biol Chem 284: 5731-5741, 2009.
96. Reddy SD, Ohshiro K, Rayala SK and Kumar R: MicroRNA-7, a homeobox D10 target, inhibits p21-activated kinase 1 and regulates its functions. Cancer Res 68: 8195-8200, 2008.

97. Kumar R, Gururaj AE and Barnes CJ: p21-activated kinases in cancer. Nat Rev Cancer 6: 459-471, 2006.

98. Aoki H, Yokoyama T, Fujiwara K, Tari AM, Sawaya R, Suki D, Hess KR, Aldape KD, Kondo S, Kumar R and Kondo Y: Phosphorylated Pak1 level in the cytoplasm correlates with shorter survival time in patients with glioblastoma. Clin Cancer Res 13: 6603-6609, 2007.

99. Miska EA, Alvarez-Saavedra E, Townsend M, Yoshii A, Sestan N, Rakic P, Constantine-Paton M and Horvitz HR: Microarray analysis of microRNA expression in the developing mammalian brain. Genome Biol 5: 68, 2004

100. Shi L, Cheng Z, Zhang J, Li R, Zhao P, Fu Z and You Y: hsa-mir181a and hsa-mir-181b function as tumor suppressors in human glioma cells. Brain Res 1236: 185-193, 2008.

101. Slaby O, Lakomy R, Fadrus P, Hrstka R, Kren L, Lzicarova E, Smrcka M, Svoboda M, Dolezalova H, Novakova J, Valik D, Vyzula R and Michalek J: MicroRNA-181 family predicts response to concomitant chemoradiotherapy with temozolomide in glioblastoma patients. Neoplasma 57: 264-269, 2010.

102. Gao FB: Posttranscriptional control of neuronal development by microRNA networks. Trends Neurosci 31: 20-26, 2008.

103. Krichevsky AM, King KS, Donahue CP, Khrapko K and Kosik KS: A microRNA array reveals extensive regulation of microRNAs during brain development. RNA 9: 1274-1281, 2003.

104. Smirnova L, Grafe A, Seiler A, Schumacher S, Nitsch R and Wulczyn FG: Regulation of miRNA expression during neural cell specification. Eur J Neurosci 21: 1469-1477, 2005.

105. Krichevsky AM, Sonntag KC, Isacson O and Kosik KS: Specific microRNAs modulate embryonic stem cell-derived neurogenesis. Stem Cells 24: 857-864, 2006.

106. Wu L and Belasco JG: Micro-RNA regulation of the mammalian lin-28 gene during neuronal differentiation of embryonal carcinoma cells. Mol Cell Biol 25: 9198-9208, 2005.

107. Le MT, Teh C, Shyh-Chang N, Xie H, Zhou B, Korzh V, Lodish HF and Lim B: MicroRNA-125b is a novel negative regulator of p53. Genes Dev 23: 862-876, 2009.

108. Xia HF, He TZ, Liu CM, Cui Y, Song PP, Jin XH and Ma X: MiR-125b expression affects the proliferation and apoptosis of human glioma cells by targeting Bmf. Cell Physiol Biochem 23: 347-358, 2009

109. Puthalakath H, Villunger A, O'Reilly LA, Beaumont JG, Coultas L, Cheney RE, Huang DC and Strasser A: Bmf: a proapoptotic $\mathrm{BH} 3$-only protein regulated by interaction with the myosin $\mathrm{V}$ actin motor complex, activated by anoikis. Science 293: 1829, 2001.

110. Cortez MA, Nicoloso MS, Shimizu M, Rossi S, Gopisetty G, Molina JR, Carlotti C Jr, Tirapelli D, Neder L, Brassesco MS, Scrideli CA, Tone LG, Georgescu MM, Zhang W, Puduvalli V and Calin GA: miR-29b and miR-125a regulate podoplanin and suppress invasion in glioblastoma. Genes Chromosomes Cancer 49: 981-990, 2010

111. Kefas B, Comeau L, Floyd DH, Seleverstov O, Godlewski J, Schmittgen T, Jiang J, diPierro CG, Li Y, Chiocca EA, Lee J, Fine H, Abounader R, Lawler S and Purow B: The neuronal micro-RNA miR-326 acts in a feedback loop with notch and has therapeutic potential against brain tumors. J Neurosci 29: 15161-15168, 2009.

112. Kim H, Huang W, Jiang X, Pennicooke B, Park PJ and Johnson MD: Integrative genome analysis reveals an oncomir/oncogene cluster regulating glioblastoma survivorship. Proc Natl Acad Sci USA 107: 2183-2188, 2010.

113. Su B, Cheng J, Yang J and Guo Z: MEKK2 is required for T-cell receptor signals in JNK activation and interleukin-2 gene expression. J Biol Chem 276: 14784-14790, 2001.

114. Sasayama T, Nishihara M, Kondoh T, Hosoda K and Kohmura E: MicroRNA-10b is overexpressed in malignant glioma and associated with tumor invasive factors, uPAR and RhoC. Int J Cancer 125: 1407-1413, 2009.

115. Xia H, Qi Y, Ng SS, Chen X, Chen S, Fang M, Li D, Zhao Y, Ge R, Li G, Chen Y, He ML, Kung HF, Lai L and Lin MC: MicroRNA-15b regulates cell cycle progression by targeting cyclins in glioma cells. Biochem Biophys Res Commun 380: 205-210, 2009

116. Xia H, Qi Y, Ng SS, Chen X, Li D, Chen S, Ge R, Jiang S, Li G, Chen Y, He ML, Kung HF, Lai L and Lin MC: microRNA-146b inhibits glioma cell migration and invasion by targeting MMPs. Brain Res 1269: 158-165, 2009. 
117. Würdinger T, Tannous BA, Saydam O, Skog J, Grau S, Soutschek J, Weissleder R, Breakefield XO and Krichevsky AM: miR-296 regulates growth factor receptor overexpression in angiogenic endothelial cells. Cancer Cell 14: 382-393, 2008.

118. Xu H, Cheung IY, Guo HF and Cheung NK: MicroRNA miR-29 modulates expression of immunoinhibitory molecule B7-H3: potential implications for immune based therapy of human solid tumors. Cancer Res 69: 6275-6281, 2009.

119. Monzo M, Navarro A, Bandres E, Artells R, Moreno I, Gel B, Ibeas R, Moreno J, Martinez F, Diaz T, Martinez A, Balagué O and Garcia-Foncillas J: Overlapping expression of microRNAs in human embryonic colon and colorectal cancer. Cell Res 18 823-833, 2008.

120. Navarro A, Marrades RM, Viñolas N, Quera A, Agustí C, Huerta A, Ramirez J, Torres A and Monzo M: MicroRNAs expressed during lung cancer development are expressed in human pseudoglandular lung embryogenesis. Oncology 76 : 162-169, 2009.

121. Ernst A, Campos B, Meier J, Devens F, Liesenberg F, Wolter M, Reifenberger G, Herold-Mende C, Lichter P and Radlwimmer B: De-repression of CTGF via the miR-17-92 cluster upon differentiation of human glioblastoma spheroid cultures. Oncogene 29: 3411-3422, 2010.

122. Ferrara N: Role of vascular endothelial growth factor in physiologic and pathologic angiogenesis: therapeutic implications. Semin Oncol 29: 10-14, 2002.

123. Inoki I, Shiomi T, Hashimoto G, Enomoto H, Nakamura H, Makino K, Ikeda E, Takata S, Kobayashi K and Okada Y: Connective tissue growth factor binds vascular endothelial growth factor (VEGF) and inhibits VEGF-induced angiogenesis. FASEB J 16: 219-221, 2002.

124. Suárez Y,Fernández-Hernando C, Yu J, Gerber SA, Harrison KD Pober JS, Iruela-Arispe ML, Merkenschlager M and Sessa WC: Dicer-dependent endothelial microRNAs are necessary for postnatal angiogenesis. Proc Natl Acad Sci USA 105: 1408214087, 2008

125. Boyerinas B, Park SM, Hau A, Murmann AE and Peter ME: The role of let-7 in cell differentiation and cancer. Endocr Relat Cancer 17: 19-36, 2010

126. Johnson SM, Grosshans H, Shingara J, Byrom M, Jarvis R, Cheng A, Labourier E, Reinert KL, Brown D and Slack FJ: RAS is regulated by the let-7 microRNA family. Cell 120: 635-647, 2005.

127. Mayr C, Hemann MT and Bartel DP: Disrupting the pairing between let-7 and Hmga2 enhances oncogenic transformation. Science 315: 1576-1579, 2007.

128. Nakada M, Niska JA, Tran NL, McDonough WS and Berens ME: EphB2/R-Ras signaling regulates glioma cell adhesion, growth, and invasion. Am J Pathol 167: 565-576, 2005.

129. Perkins E, Calvert J,Lancon JA, Parent AD and Zhang J: Inhibition of H-ras as a treatment for experimental brain C6 glioma. Brain Res Mol Brain Res 111: 42-51, 2003

130. Goldberg L and Kloog Y: A Ras inhibitor tilts the balance between Rac and Rho and blocks phosphatidylinositol 3-kinasedependent glioblastoma cell migration. Cancer Res 66: 11709-11717, 2006.

131. Lee ST, Chu K, Oh HJ, Im WS, Lim JY, Kim SK, Park CK, Jung KH, Lee SK, Kim M and Roh JK: Let-7 microRNA inhibits the proliferation of human glioblastoma cells. J Neurooncol 102: 19-24, 2011.

132. Hanahan D and Weinberg RA: The hallmarks of cancer. Cell 100: 57-70, 2000.

133. Cho RW and Clarke MF: Recent advances in cancer stem cells. Curr Opin Genet Dev 18: 48-53, 2008

134. Singh SK, Hawkins C, Clarke ID, Squire JA, Bayani J, Hide T, Henkelman RM, Cusimano MD and Dirks PB: Identification of human brain tumour initiating cells. Nature 432: 396-401, 2004.

135. Galli R, Binda E, Orfanelli U, Cipelletti B, Gritti A, De Vitis S, Fiocco R, Foroni C, Dimeco F and Vescovi A: Isolation and characterization of tumorigenic, stem-like neural precursors from human glioblastoma. Cancer Res 64: 7011-7021, 2004.

136. Singh SK, Clarke ID, Terasaki M, Bonn VE, Hawkins C, Squire J and Dirks PB: Identification of a cancer stem cell in human brain tumors. Cancer Res 63: 5821-5828, 2003.

137. Bao S, Wu Q, McLendon RE, Hao Y, Shi Q, Hjelmeland AB, Dewhirst MW, Bigner DD and Rich JN: Glioma stem cells promote radioresistance by preferential activation of the DNA damage response. Nature 444: 756-760, 2006.
138. Johannessen TC, Wang J, Skaftnesmo KO, Sakariassen P Enger PØ, Petersen K, Øyan AM, Kalland KH, Bjerkvig R and Tysnes BB: Highly infiltrative brain tumours show reduced chemosensitivity associated with a stem cell-like phenotype. Neuropathol Appl Neurobiol 35: 380-393, 2009.

139. Liu G, Yuan X, Zeng Z, Tunici P, Ng H, Abdulkadir IR, Lu L, Irvin D, Black KL and Yu JS: Analysis of gene expression and chemoresistance of $\mathrm{CD}_{133^{+}}$cancer stem cells in glioblastoma. Mol Cancer 5: 67, 2006.

140. Hatfield S and Ruohola-Baker H: MicroRNA and stem cell function. Cell Tissue Res 331: 57-66, 2008.

141. Murchison EP, Partridge JF, Tam OH, Cheloufi S and Hannon GJ: Characterization of dicerdeficient murine embryonic stem cells. Proc Natl Acad Sci USA 102: 12135-12140, 2005.

142. Bernstein E, Kim SY, Carmell MA, Murchison EP, Alcorn H, Li MZ, et al: Dicer is essential for mouse development. Nat Genet 35: 215-217, 2003

143. Christensen M and Schratt GM: MicroRNA involvement in developmental and functional aspects of the nervous system and in neurological diseases. Neurosci Lett 466: 55-62, 2009.

144. Doetsch F, Caillé I, Lim DA, García-Verdugo JM and AlvarezBuylla A: Subventricular zone astrocytes are neural stem cells in the adult mammalian brain. Cell 97: 703-716, 1999.

145. Reynolds BA, Tetzlaff W and Weiss S: A multipotent EGF-responsive striatal embryonic progenitor cell produces neurons and astrocytes. J Neurosci 12: 4565-4574, 1992.

146. Papagiannakopoulos T and Kosik KS: MicroRNAs: regulators of oncogenesis and stemness. BMC Med 6: 15, 2008.

147. Hemmati HD, Nakano I, Lazareff JA, Masterman-Smith M, Geschwind DH, Bronner-Fraser M and Kornblum HI: Cancerous stem cells can arise from pediatric brain tumors. Proc Natl Acad Sci USA 100: 15178-15183, 2003.

148. Lavon I, Zrihan D, Granit A, Einstein O, Fainstein N, Cohen MA, Cohen MA, Zelikovitch B, Shoshan Y, Spektor S, Reubinoff BE, Felig Y, Gerlitz O, Ben-Hur T, Smith Y and Siegal T: Gliomas display a microRNA expression profile reminiscent of neural precursor cells. Neurooncology 12: 422-433, 2010.

149. Calin GA and Croce CM: Chromosomal rearrangements and microRNAs: a new cancer link with clinical implications. J Clin Invest 117: 2059-2066, 2007

150. Hu J, Jiang C, Ng HK, Pang JC and Tong CY: Chromosome $14 \mathrm{q}$ may harbor multiple tumor suppressor genes in primary glioblastoma multiforme. Chin Med J (Engl) 115: 1201-1204, 2002.

151. Felsberg J, Yan PS, Huang TH, Milde U, Schramm J, Wiestler OD, Reifenberger G, Pietsch T and Waha A: DNA methylation and allelic losses on chromosome arm $14 \mathrm{q}$ in oligodendroglial tumours. Neuropathol Appl Neurobiol 32: 517-524, 2006.

152. Huang Q, Gumireddy K, Schrier M, le Sage C, Nagel R, Nair S, Egan DA, Li A, Huang G, Klein-Szanto AJ, Gimotty PA, Katsaros D, Coukos G, Zhang L, Puré E and Agami R: The microRNAs miR-373 and miR-520c promote tumour invasion and metastasis. Nat Cell Biol 10: 202-210, 2008.

153. He H, Jazdzewski K, Li W, Liyanarachchi S, Nagy R, Volinia S, Calin GA, Liu CG, Franssila K, Suster S, Kloos RT, Croce CM and de la Chapelle A: The role of microRNA genes in papillary thyroid carcinoma. Proc Natl Acad Sci USA 102: 19075-19080, 2005.

154. Laurent LC, Chen J, Ulitsky I, Mueller FJ, Lu C, Shamir R, Fan JB and Loring JF: Comprehensive microRNA profiling reveals a unique human embryonic stem cell signature dominated by a single seed sequence. Stem Cells 26: 1506-1516, 2008.

155. Card DA, Hebbar PB, Li L, Trotter KW, Komatsu Y, Mishina Y and Archer TK: Oct4/Sox2-regulated miR-302 targets cyclin D1 in human embryonic stem cells. Mol Cell Biol 28: 6426-6438, 2008.

156. Hatfield SD, Shcherbata HR, Fischer KA, Nakahara K, Carthew RW and Ruohola-Baker H: Stem cell division is regulated by the microRNA pathway. Nature 435: 974-978, 2005.

157. Shi L, Zhang J, Pan T, Zhou J, Gong W, Liu N, Fu Z and You Y: MiR-125b is critical for the suppression of human U251 glioma stem cell proliferation. Brain Res 1312: 120-126, 2010.

158. Kefas B, Comeau L, Erdle N, Montgomery E, Amos S and Purow B: Pyruvate kinase M2 is a target of the tumor-suppressive microRNA-326 and regulates the survival of glioma cells. Neurooncology 12: 1102-1112, 2010.

159. Gajjar A, Hernan R, Kocak M, Fuller C, Lee Y, McKinnon PJ, Wallace D, Lau C, Chintagumpala M, Ashley DM, Kellie SJ, Kun L and Gilbertson RJ: Clinical, histopathologic, and molecular markers of prognosis: toward a new disease risk stratification system for medulloblastoma. J Clin Oncol 22: 984-993, 2004. 
160. Gillbertson RJ and Ellison DW: The origins of medulloblastoma subtypes. Annu Rev Pathol 3: 341-365, 2008.

161. Packer RJ, Rood BR and MacDonald TJ: Medulloblastoma: present concepts of stratification into risk groups. Pediatr Neurosurg 39: 60-67, 2003

162. Lamont JM, McManamy CS, Pearson AD, Clifford SC and Ellison DW: Combined histopathological and molecular cytogenetic stratification of medulloblastoma patients. Clin Cancer Res 10: 5482-5493, 2004.

163. Ellison DW, Clifford SC, Gajjar A and Gilbertson RJ: What's new in neuro-oncology? Recent advances in medulloblastoma. Eur J Paediatr Neurol 7: 53-66, 2003.

164. Finlay JL, Erdreich-Epstein A and Packer RJ: Progress in the treatment of childhood brain tumors: no room for complacency. Pediatr Hematol Oncol 24: 79-84, 2007.

165. Ferretti E, De Smaele E, Po A, Di Marcotullio L, Tosi E, Espinola MS, Di Rocco C, Riccardi R, GiangasperoF,Farcomeni A, Nofroni I, Laneve P, Gioia U, Caffarelli E, Bozzoni I, Screpanti I and Gulino A: MicroRNA profiling in human medulloblastoma. Int J Cancer 124: 568-577, 2009

166. MacDonald TJ, Brown KM, LaFleur B, Peterson K, Lawlor C, Chen Y,Packer RJ, Cogen P and Stephan DA: Expression profiling of medulloblastoma: PDGFRA and the RAS/MAPK pathway as therapeutic targets for metastatic disease. Nat Genet 29: 143-152, 2001 .

167. Herms J, Neidt I, Lüscher B, Sommer A, Schürmann P, Schröder T, Bergmann M, Wilken B, Probst-Cousin S, HernáizDriever P, Behnke J, Hanefeld F, Pietsch T and Kretzschmar HA: C-MYC expression in medulloblastoma and its prognostic value. Int J Cancer 89: 395-402, 2000

168. Pierson J, Hostager B, Fan R and Vibhakar R: Regulation of cyclin-dependent kinase 6 by microRNA 124 in medulloblastoma. J Neurooncol 90: 1-7,2008.

169. Wu J and Xie X: Comparative sequence analysis reveals an intricate network among REST, CREB and miRNA in mediating neuronal gene expression. Genome Biol 7: 85, 2006.

170. Visvanathan J, Lee S, Lee B, Lee JW and Lee SK: The microRNA miR-124 antagonizes the anti-neural REST/SCP1 pathway during embryonic CNS development. Genes Dev 21: 744-749, 2007.

171. Lawinger P, Venugopal R, Guo ZS, Immaneni A, Sengupta D, Lu W, Rastelli L, Marin Dias Carneiro A, Levin V, Fuller GN, Echelard Y and Majumder S: The neuronal repressor REST/ NRSF is an essential regulator in medulloblastoma cells. Nat Med 6: 826-831, 2000

172. Fuller GN, Su X, Price RE, Cohen ZR, Lang FF, Sawaya R and Majumder S: Many human medulloblastoma tumors overexpress repressor element-1 silencing transcription (REST)/neuronrestrictive silencer factor, which can be functionally countered by REST-VP16. Mol Cancer Ther 4: 343-349, 2005.

173. Su X, Gopalakrishnan V, Stearns D, Aldape K, Lang FF, Fuller G, Snyder E, Eberhart CG and Majumder S: Abnormal expression of REST/NRSF and Myc in neural stem/progenitor cells causes cerebellar tumors by blocking neuronal differentiation. Mol Cell Biol 26: 1666-1678, 2006.

174. Conaco C, Otto S, Han JJ and Mandel G: Reciprocal actions of REST and a microRNA promote neuronal identity. Proc Natl Acad Sci USA 103: 2422-2427, 2006

175. Mendrzyk F, Radlwimmer B, Joos S, Kokocinski F, Benner A, Stange DE, Neben K, Fiegler H, Carter NP, Reifenberger G, Korshunov A and Lichter P: Genomic and protein expression profiling identifies CDK6 as novel independent prognostic marker in medulloblastoma. J Clin Oncol 2: 8853-8562, 2005.

176. Li KK, Pang JC, Ching AK, Wong CK, Kong X, Wang Y, Zhou L, Chen $\mathrm{Z}$ and $\mathrm{Ng} \mathrm{HK}$ : miR-124 is frequently down-regulated in medulloblastoma and is a negative regulator of SLC16A1. Hum Pathol 40: 1234-1243, 2009.

177. Liu W, Gong YH, Chao TF, Peng XZ, Yuan JG, Ma ZY, Jia G and Zhao JZ: Identification of differentially expressed microRNAs by microarray: a possible role for microRNAs gene in medulloblastomas. Chin Med J (Engl) 122: 2405-2411, 2009.

178. Ruiz I, Altaba A, Sánchez P and Dahmane N: Gli and hedgehog in cancer: tumours, embryos and stem cells. Nat Rev Cancer 2 361-372, 2002.

179. Kimura H, Stephen D, Joyner A and Curran T: Gli1 is important for medulloblastoma formation in $\mathrm{Ptcl}^{+/}$mice. Oncogene 24: 4026-4036, 2005.

180. Ferretti E, De Smaele E, Miele E, Laneve P, Po A, Pelloni M, Paganelli A, Di Marcotullio L, Caffarelli E, Screpanti I, Bozzoni I and Gulino A: Concerted microRNA control of Hedgehog signalling in cerebellar neuronal progenitor and tumour cells. EMBO J 27: 2616-2627, 2008.
181. Ferretti E, De Smaele E, Di Marcotullio L, Screpanti I and Gulino A: Hedgehog checkpoints in medulloblastoma: the chromosome 17p deletion paradigm Trends Mol Med 11: 537-545, 2005.

182. Uziel T, Karginov FV, Xie S, Parker JS, Wang YD, Gajjar A, He L, Ellison D, Gilbertson RJ, Hannon G and Roussel MF: The miR-17 92 cluster collaborates with the Sonic Hedgehog pathway in medulloblastoma. Proc Natl Acad Sci USA 106 2812-2817, 2009.

183. Northcott PA, Fernandez-L A, Hagan JP, Ellison DW, Grajkowska W, Gillespie Y, Grundy R, van Meter T, Rutka JT, Croce CM, Kenney AM and Taylor MD: The miR-17/92 polycistron is up-regulated in sonic hedgehog-driven medulloblastomas and induced by $\mathrm{N}$-myc in sonic hedgehog-treated cerebellar neural precursors. Cancer Res 69: 3249-3255, 2009

184. Solecki DJ, Liu XL, Tomoda T, Fang Y and Hatten ME: Activated Notch 2 signaling inhibits differentiation of cerebellar granule neuron precursors by maintaining proliferation. Neuron 31: 557-568, 2001

185. Fan X, Mikolaenko I, Elhassan I, Ni X, Wang Y, Ball D, Brat DJ, Perry A and Eberhart CG: Notch1 and notch2 have opposite effects on embryonal brain tumor growth. Cancer Res 64: 7787-7793, 2004.

186. Ishibashi M, Moriyoshi K, Sasai Y, Shiota K, Nakanishi S and Kageyama R: Persistent expression of helix-loop-helix factor HES-1 prevents mammalian neural differentiation in the central nervous system. EMBO J 13: 1799-1805, 1994.

187. Fan X, Paetau A, Aalto Y, Välimäki M, Sane T, Poranen A, Castresana JS and Knuutila S: Gain of chromosome 3 and loss of $13 \mathrm{q}$ are frequent alterations in pituitary adenomas. Cancer Genet Cytogenet 128: 97-103, 2001.

188. Garzia L, Andolfo I, Cusanelli E, Marino N, Petrosino G, De Martino D, Esposito V, Galeone A, Navas L, Esposito S, Gargiulo S, Fattet S, Donofrio V, Cinalli G, Brunetti A, Vecchio LD, Northcott PA, Delattre O, Taylor MD, Iolascon A and Zollo M: MicroRNA-199b-5p impairs cancer stem cells through negative regulation of HES1 in medulloblastoma. PLoS One 4: 4998, 2009.

189. Lu Y, Ryan SL, Elliott DJ, Bignell GR, Futreal PA, Ellison DW, Bailey S and Clifford SC: Amplification and overexpression of Hsa-miR-30b, Hsa-miR-30d and KHDRBS3 at 8q24.22-q24.23 in medulloblastoma. PLoS One 4: 6159, 2009.

190. Venkataraman S, Alimova I, Fan R, Harris P, Foreman N and Vibhakar R: MicroRNA 128a increases intracellular ROS level by targeting Bmi-1 and inhibits medulloblastoma cancer cell growth by promoting senescence. PLoS One 5: 10748, 2010.

191. Leung C,Lingbeek M, Shakhova O,Liu J, TangerE, Saremaslani P, van Lohuizen M and Marino S: Bmil is essential for cerebellar development and is overexpressed in human medulloblastomas. Nature 428: 337-341, 2004

192. Diehn M, Cho RW, Lobo NA, Kalisky T, Dorie MJ, Kulp AN Qian D, Lam JS, Ailles LE, Wong M, Joshua B, Kaplan MJ, Wapnir I, Dirbas FM, Somlo G, Garberoglio C, Paz B, Shen J, Lau SK, Quake SR, Brown JM, Weissman IL and Clarke MF: Association of reactive oxygen species levels and radioresistance in cancer stem cells. Nature 458: 780-783, 2009.

193. Vandeva S, Jaffrain-Rea ML, Daly AF, Tichomirowa M, Zacharieva $S$ and Beckers A: The genetics of pituitary adenomas. Best Pract Res Clin Endocrinol Metab 24: 461-476, 2010.

194. Ezzat S and Asa SL: Mechanisms of disease: the pathogenesis of pituitary tumors. Nat Clin Pract Endocrinol Metab 2: 220-230, 2006.

195. Bottoni A, Piccin D, Tagliati F, Luchin A, Zatelli MC and Degli Uberti EC: miR-15a and miR-16-1 down-regulation in pituitary adenomas. J Cell Physiol 204: 280-285, 2005.

196. Cheng AM, Byrom MW, Shelton J and Ford LP: Antisense inhibition of human miRNAs and indications for an involvement of miRNA in cell growth and apoptosis. Nucleic Acids Res 33: 1290-1297, 2005.

197. Cimmino A, Calin GA, Fabbri M, Iorio MV, Ferracin M, Shimizu M, Wojcik SE, Aqeilan RI, Zupo S, Dono M, Rassenti L, Alder H, Volinia S, Liu CG, Kipps TJ, Negrini M and Croce CM: miR-15 and miR-16 induce apoptosis by targeting BCL2. Proc Natl Acad Sci USA 102: 13944-13949, 2005.

198. Wang DG, Johnston CF, Atkinson AB, Heaney AP, Mirakhur M and Buchanan KD: Expression of bcl-2 oncoprotein in pituitary tumours: comparison with c-myc. J Clin Pathol 49: 795-797, 1996.

199. Bottoni A, Zatelli MC, Ferracin M, Tagliati F, Piccin D, Vignali C, Calin GA, Negrini M, Croce CM and Degli Uberti EC: Identification of differentially expressed microRNAs by microarray: a possible role for microRNA genes in pituitary adenomas. J Cell Physiol 210: 370-377, 2007. 
200. Amaral FC, Torres N, Saggioro F, Neder L, Machado HR, Silva WA Jr, Moreira AC and Castro M: MicroRNAs differentially expressed in ACTH-secreting pituitary tumors. J Clin Endocrinol Metab 94: 320-323, 2009.

201. Zhou G, Bao ZQ and Dixon JE: Components of a new human protein kinase signal transduction pathway. J Biol Chem 270 12665-12669, 1995.

202. Qian ZR, Asa SL, Siomi H, Siomi MC, Yoshimoto K, Yamada S, Wang EL, Rahman MM, Inoue H, Itakura M, Kudo E and Sano T: Overexpression of HMGA2 relates to reduction of the let-7 and its relationship to clinicopathological features in pituitary adenomas. Mod Pathol 22: 431-441, 2009.

203. Lee YS and Dutta A: The tumor suppressor microRNA let-7 represses the HMGA2 oncogene. Genes Dev 21: 1025-1030, 2007.

204. Finelli P, Pierantoni GM, Giardino D, Losa M, Rodeschini O, Fedele M, Valtorta E, Mortini P, Croce CM,Larizza L and Fusco A: The High Mobility Group A2 gene is amplified and overexpressed in human prolactinomas. Cancer Res 62: 2398-2405, 2002.

205. Pierantoni GM, Finelli P, Valtorta E, Giardino D, Rodeschini O, Esposito F, Losa M, Fusco A and Larizza L: High-mobility group A2 gene expression is frequently induced in non-functioning pituitary adenomas (NFPAs), even in the absence of chromosome 12 polysomy. Endocr Relat Cancer 12: 867-874, 2005.
206. Butz H, Likó I, Czirják S, Igaz P, Khan MM, Zivkovic V, Bálint K, Korbonits M, Rácz K and Patócs A: Down-regulation of Weel kinase by a specific subset of microRNA in human sporadic pituitary adenomas. J Clin Endocrinol Metab 95: 181-191, 2010

207. Lu J, Getz G, Miska EA, Alvarez-Saavedra E, Lamb J, Peck D, Sweet-Cordero A, Ebert BL, Mak RH, Ferrando AA, Downing JR, Jacks T, Horvitz HR and Golub TR: MicroRNA expression profiles classify human cancers. Nature 435: 834-838, 2005.

208. Nicoloso MS and Calin GA: MicroRNA involvement in brain tumors: from bench to bedside. Brain Pathol 18: 122-129, 2008

209. Mathupala SP, Mittal S, Guthikonda M and Sloan AE MicroRNA and brain tumors: a cause and a cure? DNA Cell Biol 26: 301-310, 2007

210. Purow B: The elephant in the room: do microRNA-based therapies have a realistic chance of succeeding for brain tumors such as glioblastoma? J Neurooncol 103: 429-436, 2011.

211. Katakowski M, Buller B, Wang X, Rogers T and Chopp M: Functional microRNA is transferred between glioma cells. Cancer Res 70: 8259-8263, 2010. 